\title{
Cyclic Lipodepsipeptides in Novel Antimicrobial Drug Discovery ${ }^{\dagger}$
}

\author{
Nina Bionda and Predrag Cudic* \\ Torrey Pines Institute for Molecular Studies, 11350 SW Village Parkway, Port St. Lucie, FL 34987, USA
}

RECEIVED DECEMBER 22, 2010; REVISED MARCH 11, 2011; ACCEPTED MARCH 17, 2011

\begin{abstract}
Naturally occurring cyclic depsipeptides, microbial secondary metabolites that contain one or more ester bonds in addition to the amide bonds, have emerged as an important source of pharmacologically active compounds or promising lead structures for the development of novel synthetically derived drugs. In particular, their lipidated derivatives have shown the greatest therapeutic potential as antimicrobial agents. Some of those compounds are either already marketed (daptomycin 37) or in advanced stages of clinical development (ramoplanin 32) for the treatment of complicated infections caused by multidrug-resistant bacterial strains. As bacteria progressively become resistant to frontline antimicrobial agents, our capacity to effectively treat bacterial infections becomes severely hindered. Therefore, identifying novel antibacterial targets and new antibacterial chemotherapeutics capable of treating infections from drug-resistant microorganisms is of vital importance.(doi: 10.5562/cca1819)
\end{abstract}

Keywords: antibiotic, cyclic, lipodepsipeptide

\section{INTRODUCTION}

Historically natural products have served as important sources of pharmacologically active compounds or lead structures for the development of new drugs. ${ }^{1-3}$ Although natural product research efforts have recently lost popularity in the industry, ${ }^{4}$ a large number (over $25 \%$ ) of new drugs approved between 1981 and 2006 are of natural origin. ${ }^{5-7}$ Among natural products, peptides are particularly interesting because of the key roles they play in biological processes. In 2004 more than 40 peptides were in the world market for clinical applications, and more than 400 were in advanced preclinical phases worldwide. ${ }^{8}$ Peptides' potential for high efficacy and their minimal side effects combined with advances in solid-phase synthetic chemistry, purification technology and new strategies for peptide drug delivery made them widely considered as lead compounds in drug development. ${ }^{9-11}$ At present, peptide-based therapeutics exist for a wide variety of human diseases, including osteoporosis (calcitonin), diabetes (insulin), infertility (gonadorelin), carcinoid tumors and acromegaly (octreotide), hypothyroidism (thyrotropin-releasing hormone [TRH]), and bacterial infections (vancomycin, daptomycin). ${ }^{12}$

However, despite the great potential, there are still some limitations for peptides as drugs per se. Major disadvantages are short half-life, rapid metabolism, and poor oral bioavailability. ${ }^{13}$ Nevertheless, pharmacoki- netic properties of peptides can be improved by various modifications. ${ }^{12}$ Peptidomimetic modifications or cyclization of linear peptides are frequently used as an attractive method to provide more conformationally constrained and thus more stable and bioactive peptides. ${ }^{14-19}$ In addition, replacement of the amide groups that undergo proteolytic hydrolysis with ester groups may lead to longer-acting compounds not so prone to proteolysis. ${ }^{20-23}$ Considering all these modifications that can potentially improve peptide metabolic stability, naturally occurring cyclic depsipeptides that contain one or more ester bonds in addition to the amide bonds have emerged as promising lead compounds for drug discovery. Cyclic depsipeptides belong to a large and diverse family of nonribosomally synthesized peptides that have a wide variety of important biological activities. $^{24,25}$ The biosynthesis of these peptides proceeds nonribosomally and is catalyzed by complex multi-functional enzymes; termed non-ribosomal peptide synthases (NRPSs). NRPSs have unique modular structure in which each module contains the requisite domains for the recognition and activation of a single amino acid, generating huge structural and functional diversity of nonribosomal peptides. ${ }^{26}$ It is very well documented that cyclic depsipeptides and their lipidated derivatives exhibit a broad spectrum of biological activities including insecticidal, antiviral, antimicrobial, antitumor, tumorpromotive, anti-inflammatory, and

\footnotetext{
$\dagger$ This article belongs to the Special Issue Chemistry of Living Systems devoted to the intersection of chemistry with life.

* Author to whom correspondence should be addressed. (E-mail: pcudic@tpims.org)
} 
immunosuppressive actions. Perhaps, lipidated cyclic depsipeptides have shown the greatest therapeutic potentials, particularly as antimicrobial agents. There are numerous literature reports describing their isolation, characterization, and antimicrobial activities. Here, we summarize all these efforts, and discuss the role and applications of cyclic lipodepsipeptides from a new antibiotic discovery perspective.

\section{KATANOSIN A AND LYSOBACTIN (KATANOSIN B)}

Katanosin A 1 and lysobactin 2 (also known as katano$\sin$ B) are lipophilic, cyclic depsipeptides isolated in 1988 independently from two sources. Shionogi \& Co., Japan, isolated the two natural products from a strain related to the genus Cytophaga, whereas the Squibb Institute, USA, isolated lysobactin from Lysobacter sp. SC $14067 .{ }^{27-30}$ These two natural products have a macrocyclic core composed of nine amino acids connected via lactone bridge between L-threo- $\beta$-phenylserine (L$t$ PhSer) and C-terminal L-Ser ${ }^{11}$. A hydrophobic D-LeuL-Leu side chain is attached to the N-terminus of L$t \mathrm{PhSer}^{3}$, Figure 1. Out of eleven amino acids, six are nonproteinogenic, including L- $t \mathrm{PhSer}$, L-threo- $\beta$ hydroxyaspartic acid (L- $t$ HyAsp), L-hydroxyleucine (LHyLeu), L-allo-threonine (L-aThr) and two D-amino acids, D-Arg and D-Leu. The main structural difference between katanosins A $\mathbf{1}$ and lysobactin (katanosin B) $\mathbf{2}$ lies in the amino acid residue at position 7, Figure 1. Katanosin A contains a Val residue, whereas lysobactin contains Ile residue. ${ }^{27-29,31,32}$ Several groups have reported synthesis of lysobactin fragments, ${ }^{33-38}$ and an Fmoc solid-phase synthesis of katanosin A and lysobac-

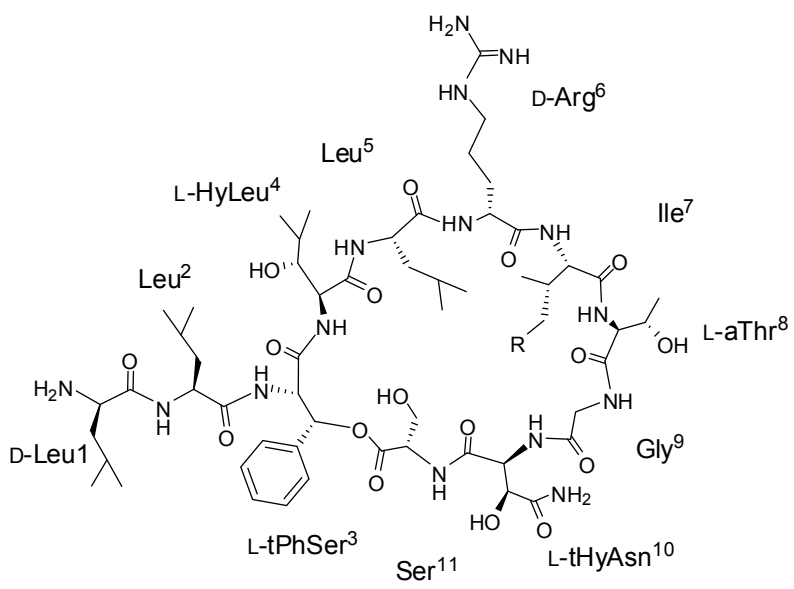

$\mathrm{R}=\mathrm{H} \quad$ Katanosin A 1

$\mathrm{R}=\mathrm{CH}_{3}$ Lysobactin (Katanosin B) 2

Figure 1. Structures of katanosin A 1 and lysobactin (katano$\sin \mathrm{B}) 2$.
Table 1. In vivo efficacy of katanosin A $\mathbf{1}$ and lysobactin (katanosin B) 2 against bacterial infection in mice $^{27}$

\begin{tabular}{lcc}
\hline & \multicolumn{2}{c}{ Antibiotic $^{\text {(a) }}$} \\
\hline Bacteria & $\begin{array}{c}\text { Katanosin A } \\
\mathrm{ED}_{50} \mathrm{mg} / \mathrm{kg} \times 2\end{array}$ & $\begin{array}{c}\text { Lysobactin } \\
(\text { Katanosin B) } \\
\mathrm{ED}_{50} \mathrm{mg} / \mathrm{kg} \times 2\end{array}$ \\
\hline S. aureus Smith & 1.20 & 0.67 \\
S. aureus SR 2030 & 1.90 & 0.77 \\
S. pyogenes C-203 & 2.86 & 1.55 \\
S. faecalis SR 700 & 2.10 & 1.80 \\
\hline (a) Compounds were administered subcutaneously at 1 and $5 \mathrm{~h}$
\end{tabular}

tin analogs containing $\mathrm{Asp}^{10}, \mathrm{Thr}^{8}$, $\mathrm{Leu}^{4}$ instead of L$t$ HyAsp $^{10}, \mathrm{~L}_{-} a \mathrm{Thr}^{8}$, and L-HyLeu ${ }^{4}$ residues has been reported by Egner and Bradley. ${ }^{39}$ The first total solution-phase syntheses of lysobactin have been reported recently. In 2007 von Nussbaum et al. at Bayer AG reported a synthesis of lysobactin rationalized by its crystal structure. ${ }^{40} \mathrm{~A}$ key step in this synthesis, peptide's macrocyclic core assembly, was achieved via conformation-directed cyclization in which $\mathrm{H}$-bonding involving unprotected hydroxyl side chains of amino acids plays a crucial role. Consequently, no side chain hydroxyl group protections are required, simplifying somewhat lysobactin's total synthesis. Shortly afterward, Van Nieuwenhze et al. reported peptide-chemistry based solution phase total synthesis of lysobactin. ${ }^{41}$

Both natural products show quite potent in vitro activity against Gram-positive bacteria such as antibiotic-resistant Staphylococcus aureus, Enterococcus faecium, Streptococcus pyogenes, Streptococcus pneumoniae and Enterococcus faecalis. Reported antibacterial activity, as indicated by the minimum inhibitory concentrations (MIC), ranged from 0.1 to $0.8 \mu \mathrm{g} / \mathrm{mL} .^{27,30}$ Katanosin $\mathrm{A}$ and lysobactin exhibit promising in vivo activity as well, as demonstrated by their curative effects when administered subcutaneously to mice infected with Gram-positive pathogens, Table $1 .{ }^{27}$ Modest to no activity against Gram-negative bacteria has been reported. $^{30}$ The spectrum of antibacterial activity for lysobactin parallels that of vancomycin, although lysobactin is four times more potent. It is, however, slightly more toxic, Table $2{ }^{27}$ In 1989 Tymiak et al. reported

Table 2. In vivo toxicity of lysobactin (katanosin B) $\mathbf{2}$ and vancomycin $^{30}$

\begin{tabular}{lll}
\hline & \multicolumn{2}{l}{$\mathrm{LD}_{50}(\mathrm{mg} / \mathrm{kg})$} \\
\cline { 2 - 3 } Antibiotic & 77 & $\mathrm{ip}^{(\mathrm{b})}$ \\
\hline Lysobactin (Katanosin B) & 732 \\
Vancomycin & $>400$ & $>1000$ \\
\hline
\end{tabular}

(a) iv = intravenously; ${ }^{(b)}$ ip = intraperitoneally. 


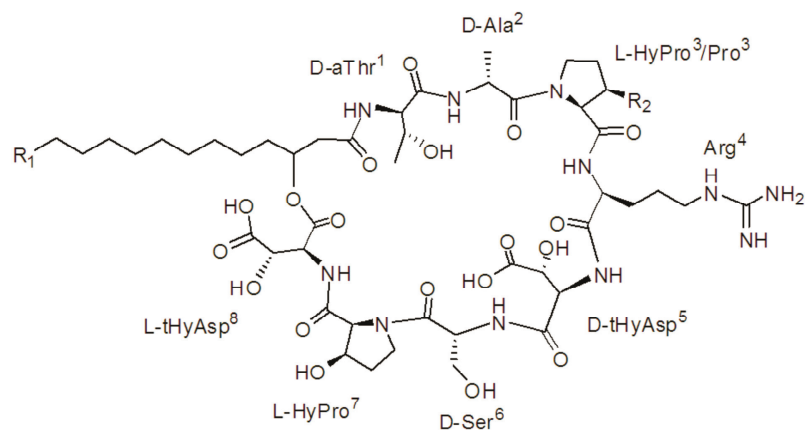

\begin{tabular}{lll}
\hline Analog & $\mathrm{R}_{1}$ & $\mathrm{R}_{2}$ \\
\hline $\mathrm{A}_{1} 3$ & $\mathrm{z}_{2}$ & $\mathrm{OH}$ \\
$\mathrm{B}_{1} 7$ & & $\mathrm{H}$ \\
$\mathrm{A}_{2} 4$ & $\mathrm{H}_{2}$ & $\mathrm{OH}$ \\
$\mathrm{B}_{2} 8$ & & $\mathrm{H}$ \\
$\mathrm{A}_{3} 5$ & & $\mathrm{OH}$ \\
$\mathrm{B}_{3} 9$ & & $\mathrm{H}$ \\
$\mathrm{A}_{4} 6$ & & $\mathrm{OH}$ \\
$\mathrm{B}_{4} 10$ & & $\mathrm{H}$ \\
\hline
\end{tabular}

Figure 2. Structures of plusbacins $A_{1}-A_{4}$ 3-6 and $B_{1}-B_{4}$ 7-10.

structure determination of lysobactin and structural requirements for its biological activity. ${ }^{31}$ Based on lysobactin's semisynthetic modifications, it was demonstrated that the macrocyclic lactone bridge and N-terminal D-Leu ${ }^{1}$ are crucial structural elements contributing to its antibacterial activity. Experiments performed by Bonner et $a l .{ }^{30}$ have suggested that lysobactin is primarily a cell wall acting agent probably affecting a step prior to UDP- $N$-acetylglucosamine formation. According to recent data published by Maki et al., ${ }^{42}$ lysobactin inhibits the transglycosylation and transpeptidation steps of bacterial cell wall biosynthesis by an unidentified mechanism that differs from the D-Ala-D-Ala binding characteristic for vancomycin, a drug of choice for treatments of infections caused by resistant bacterial strains. It was shown that lysobactin inhibits nascent peptidoglycan biosynthesis much like vancomycin; but unlike vancomycin, it also inhibits lipid intermediate formation. Interestingly, the MIC of lysobactin against S. aureus SRM133 was not affected by addition of acetyl-Lys-D-Ala-D-Ala, while the MIC of vancomycin increased significantly. ${ }^{42}$ These data strongly suggest that the inhibition of bacterial cell wall biosynthesis is a result of binding to lipid intermediates, substrates of several successive enzymes, rather than a result of the direct effect on one enzyme. However, lysobactin's mode of action is not yet precisely understood.

\section{PLUSBACINS}

Plusbacin family of antibiotics, Figure 2, were isolated in 1992 from Pseudomonas sp. strain PB-6250 by Shionogi \& Co., the same group that discovered katanosins. ${ }^{43}$ Plusbacins are eight-residue depsipeptides cyclized by a lactone bridge between the fatty acid hydroxyl group in position 3 and the C-terminal L$t$ HyAsp $^{8}$, Figure 2. Out of eight amino acids, only one is proteinogenic. The rest are D-amino acids and/or hydroxylated amino acids, including D- and L- $t$ HyAsp acid and L-hydroxyproline (L-HyPro). Plusbacins were divided into two families, $\mathrm{A}$ and $\mathrm{B}$. The family $\mathrm{A}$
$\left(A_{1}-A_{4}\right)$ contains L-HyPro ${ }^{3}$; whereas in family $B$ $\left(B_{1}-B_{4}\right)$, this residue is replaced with Pro ${ }^{3}$. The structures of fatty acids differ within the families, Figure $2{ }^{44}$ Plusbacins $A_{1} 3$ and $B_{1} 7$ have the same fatty acid, and it is assumed to be 3-hydroxy-tetradecanoic acid. Plusbacins $\mathrm{A}_{2} 4$ and $\mathrm{B}_{2} \mathbf{8}$ have 3-hydroxy-isopentadecanoic acid, $A_{3} 5$ and $B_{3} 9$ have 3-hydroxy-isohexadecanoic acid, and $\mathrm{A}_{4} 6$ and $\mathrm{B}_{4} 10$ have 3-hydroxy-hexadecanoic acid. However, the stereochemistries of the fatty acids' carbon atoms bearing hydroxyl groups were not reported. All lipodepsipeptides showed remarkable antimicrobial activity in vitro against several Gram-positive bacteria, including $E$. faecalis, vancomycin-resistant $E$. faecium (VRE) and methicillin-resistant $S$. aureus (MRSA), with MICs ranging from 0.05 to $6.3 \mu \mathrm{g} / \mathrm{mL}$. Among plusbacins, plusbacin $A_{3} 5$ showed the most potent antibacterial activity. ${ }^{42,43}$ None of the plusbacins were active against the Gram-negative bacteria tested, including Escherichia coli and Klebsiella pneumoniae. Curative effects in mice infected with $S$. aureus and $S$. pyogenes were observed with plusbacins $\mathrm{A}_{2} \mathbf{4}$ and $\mathrm{A}_{3} \mathbf{5}$, demonstrating plusbacins' in vivo potency. ${ }^{43}$ Experiments described by Maki et al. indicated that the most potent plusbacin, $\mathrm{A}_{3} \mathbf{5}$, inhibits bacterial peptidoglycan biosynthesis in the same fashion as lysobactin (katano$\sin \mathrm{B}){ }^{42}$ As in the case of lysobactin, the precise mechanism of action has yet to be determined. In 2007 VanNieuwenhze et al. reported total synthesis of plusbacin $\mathrm{A}_{3}$ in solution. ${ }^{45}$ Their synthetic approach was guided by the feasibility of the final macrolactamization step and by their hypothesis that the hydroxyproline residues may enforce a $\beta$-turn type of conformation facilitating the desired conformation during the final cyclization step. Two plusbacins $\mathrm{A}_{3}$ were synthesized differing in the stereochemistry of the fatty acid carbon atom in position 3. Comparison of these two synthetic compounds with the natural product revealed the $(R)$ configuration of the 3-hydroxyisopentanoic acid. Despite promising in vitro and in vivo antibacterial activities, there are no reports yet of clinical trials involving either lysobactin or plusbacin. 


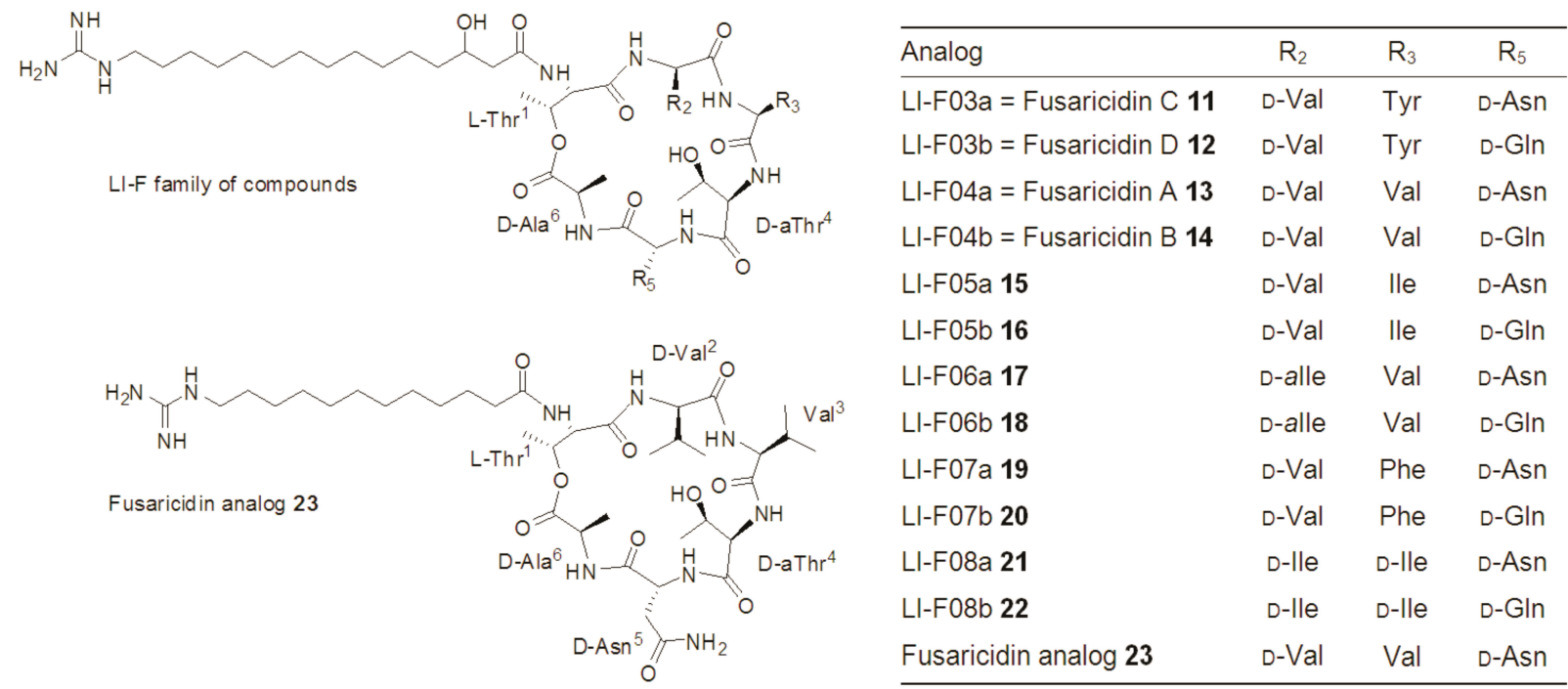

Figure 3. Structures of LI-F family of compounds 11-22 and synthetic analog 23.

\section{LI-F/FUSARICIDINS}

LI-Fs or fusaricidins are a family of cyclic lipodepsipeptide antifungal antibiotics isolated from Paenibacillus sp., Figure $3{ }^{46-48}$ Their common structural feature is the macrocyclic portion consisting of six amino acid residues, three of which, $\mathrm{Thr}^{1}, \mathrm{D}-a \mathrm{Thr}^{4}$, D-Ala ${ }^{6}$ are conserved throughout the family, and a 15-guanidino-3hydroxypentadecanoic acid attached via amide bond to the N-terminal $\mathrm{Thr}^{1}$. LI-Fs/fusaricidins are cyclized by a lactone bridge between $\mathrm{N}$-terminal $\mathrm{Thr}^{1}$ hydroxyl group and C-terminal D-Ala. ${ }^{6}$ In 1987 Kurusu and Ohba reported isolation of LI-Fs from Paenibacillus polymyxa L-1129 strain. $^{46,49}$ Although RP HPLC analysis of the antifungal antibiotics mixture isolated from the fermentation broth showed the presence of at least ten compounds, only five were isolated, which were subsequently named LI-F03, F04, F05, F07 and F08. It was also noticed that each isolated antifungal antibiotic was, in fact, a mixture of two homologous components that were not successfully separated at the time. ${ }^{46}$ In 2000 Kuroda et al. reported sequences of all isolated members of LI-F family 11-22. ${ }^{49}$ The $(R)$-configuration of fatty acid for LI-F04a 13 was determined just recently upon total synthesis of both fatty acid enantiomers and their comparison with the natural LI-F04a ${ }^{50}$ However, it is not yet known whether this stereochemistry is conserved within the family. All isolated antimicrobials showed high activity against a variety of fungi and Gram-positive bacteria, whereas no activity was observed against Gram-negative bacteria. ${ }^{46}$ Approximately ten years after the discovery of the LI-F family of antifungal antibiotics, Kajimura and Kaneda isolated a series of compounds named fusaricidins from the culture broth of $P$. polymyxa KT-8 strain. ${ }^{47,48}$ Fusaricidins A-D
11-14, Figure 3, are analogous to the LI-F family of antimicrobial antibiotics. In fact, LI-F peptides were later determined to be mixtures containing previously structurally characterized and new fusaricidins. ${ }^{49,51}$ Out of four isolated fusaricidin antibiotics, fusaricidin A (LIF04a) $13,{ }^{49}$ showed the most promising antimicrobial activity against a variety of fungi, including clinically important Candida albicans and Cryptococcus neoformans. Fusaricidin A (LI-F04a) also exhibits potent activity against Gram-positive bacteria such as $S$. aureus (MICs ranging from $0.78-3.12 \mu \mathrm{g} / \mathrm{mL}$ for most of the tested strains). LI-Fs/fusaricidins did not, however, show activity against Gram-negative bacteria. ${ }^{47,48}$ Low acute toxicity in mice have been reported for LI-F03, LI-F04, LI-F05, LI-F07, and LI-F08 (LD ${ }_{50} 150-200$ $\mathrm{mg} / \mathrm{kg}){ }^{46}$ LI-Fs/fusaricidins' mode of action is still unknown. Two solid-phase synthetic approaches toward the most active fusaricidin A (LI-F04a) $\mathbf{1 3}$ have been reported recently. Stawikowski and Cudic reported in 2006 Fmoc solid-phase synthesis of a fusaricidin A (LIF04a) analog 23 containing 12-guanidino dodecanoic acid instead of naturally occurring 15-guanidino-3hydroxyhexadecanoic acid. ${ }^{52}$ One reported synthetic approach includes resin attachment of the first amino acid, D-Asp, ${ }^{5}$ via side chain, successful combination of four quasiorthogonal temporary protecting groups, stepwise Fmoc solid-phase synthesis of a linear precursor peptide, lipid tail attachment followed by last amino acid coupling via ester bond and on-resin head-to-tail macrolactamization. This strategy allows the complete suppression of the undesired $O \rightarrow N$ acyl shift, and an efficient automated solid-phase synthesis of cyclic lipodepsipeptides. ${ }^{52}$ Since the entire synthesis was accomplished on the solid support, this opens a possibility for combinatorial modification of fusaricidin A (LI-F04a) 


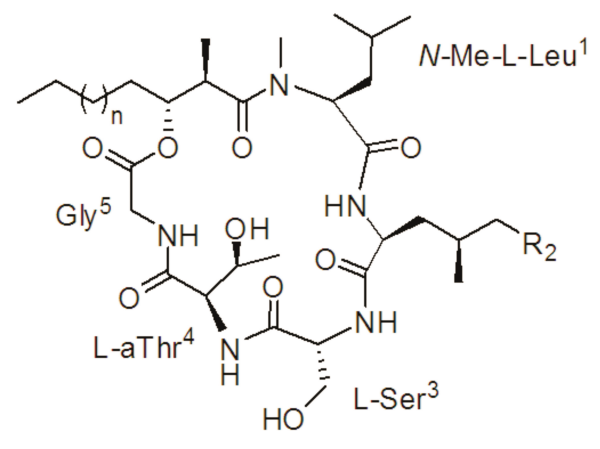

\begin{tabular}{|c|c|c|}
\hline & $\mathrm{R}_{2}$ & $n$ \\
\hline SF-1902 A (Globomycin) 24 & $\mathrm{CH}_{3}$ & 3 \\
\hline SF-1902 $\mathrm{A}_{2} 25$ & $\mathrm{CH}_{3}$ & 1 \\
\hline SF-1902 A 26 & $\mathrm{H}$ & 5 \\
\hline SF-1902 A 4 a 27 & $\mathrm{CH}_{3}$ & 4 \\
\hline SF-1902 A $4 \mathrm{~b} 28$ & $\mathrm{H}$ & 5 \\
\hline SF-1902 $A_{5} 29$ & $\mathrm{CH}_{3}$ & 5 \\
\hline
\end{tabular}

Figure 4. SF-1902 family of cyclic lipodepsipeptides 24-29.

natural products and their analogs. Total synthesis of this natural product was reported in 2010 by Cochrane et al. In this approach, a linear peptide sequence was assembled on a solid-support using Fmoc-chemistry, followed by peptide cleavage, in solution macrolactonization, and final attachment of 15-guanidino-3hydroxyhexadecanoic acid. ${ }^{50}$ Both enantiomers of this fatty acid were assembled by Yamaguchi-Hiaro alkylation of corresponding chiral epoxide precursors. By comparison of the optical rotations of both synthetic fusaricidin A (LI-F04a) analogs with the natural product, it was determined that the natural product has fatty acid with $(R)$-absolute configuration. Two groups, Jensen et al..$^{53}$ and Park et al. ${ }^{54}$ have recently reported identification and isolation of putative LI-F/fusaricidin synthetase gene, fusA, from $P$. polymyxa, opening the possibility for the development of biosynthetic approaches toward this family of naturally occurring cyclic lipodepsipeptides and their analogs.

\section{SF-1902 A FAMILY}

SF-1902 $\mathrm{A}_{1}-\mathrm{A}_{5},{ }^{55,56}$ Figure 4, are cyclic lipodepsipeptides isolated in 1978 from four different strains of actinomycetes. Their macrocyclic core is comprised of five amino acid residues and a $\beta$-hydroxy- $\alpha$-methyl carboxylic acid. One compound named SF-1902 $A_{1}$ has the same structure as globomycin ${ }^{57} \mathbf{2 4}$, whereas an additional five isolated compounds, $\mathrm{A}_{2}, \mathrm{~A}_{3}, \mathrm{~A}_{4 \mathrm{a}}, \mathrm{A}_{4 \mathrm{~b}}$ and $\mathrm{A}_{5}$ (25-29) differ in the length of the fatty acid side chains and the amino acid residue in position 2 of the peptide macrocyclic core; SF-1902 $\mathrm{A}_{3}$ and SF-1902 $\mathrm{A}_{4 b}$ have $\mathrm{Val}^{2}$ instead of L-allo-isoleucine (L-aIle ${ }^{2}$ ), Figure 4. In this family of cyclic lipodepsipeptides, lactonization occurs between C-terminal $\mathrm{Gly}^{5}$ and the fatty acid's hydroxyl group in position 3. Three amino acids are non-proteinogenic, $N$-Me-L-Leu, L- $a \mathrm{Thr}$ and L-alle. Globomycin's crystal structure reported in 2000 by Kogen et al. revealed $(R)$-configuration in both fatty acid stereocenters. ${ }^{58}$ Natural product globomycin $\mathbf{2 4}$ showed most potent activity against Gram-negative bacteria such as E. coli and K. pneumonia, with MICs of $0.2 \mu \mathrm{g} / \mathrm{mL}{ }^{57}$ Its mode of action involves inhibition of lipoprotein signal peptidase II (LspA), an integral membrane protein which processes the acylated precursor form of lipoproteins into apolipoprotein and signal peptide in bacteria. ${ }^{59,60}$ Specific inhibition of LspA leads to the accumulation of the lipoprotein precursor in the cytoplasmic membrane and consequently to bacterial cell death. ${ }^{61-63}$ Quite interestingly, Banaiee et al. demonstrated that globomycin does not inhibit LspA in Mycobacterium tuberculosis and that the mode of action against this bacterial strain lacks any LspA-dependent activity. ${ }^{64}$ Globomycin is not cytotoxic to mouse L-cells in tissue culture with a minimal toxic concentration of $250 \mu \mathrm{g} / \mathrm{mL}$. The $\mathrm{LD}_{50}$ value for intraperitoneal injection in mice was $115 \mathrm{mg} / \mathrm{kg}$, but mice tolerated up to 400 $\mathrm{mg} / \mathrm{kg}$ when administered subcutaneously. ${ }^{57}$

The total solution synthesis and structure-activity relationship (SAR) study reported by Kogen et al..$^{58,65}$ showed that the hydroxyl group in the $\mathrm{Ser}^{3}$ residue is essential for antibacterial activity, and the presence of a longer fatty acid side chain significantly increased the activity. A four-carbon atom increase in the fatty acid side chain length, from nine to thirteen carbons, led to a four- to eight-fold increase in activity against all Gramnegative bacteria tested. Surprisingly, the globomycin synthetic analog containing the longest fatty acid side chain, 30, exhibited also activity against Gram-positive S. aureus strains with MICs ranging from 6.25 to 12.5 $\mu \mathrm{g} / \mathrm{ml}$, Table $3 .{ }^{65,66}$ On the other hand, derivatives with a modified macrocyclic core exhibited weak or no activity. For example, it was demonstrated that the L-aThr hydroxyl group is not important for activity, but its stereochemistry turned out to be essential. Modifications at the $N$-Me position caused conformational change in the peptide resulting in a loss of the bacteri-

Table 3. Antibacterial activity of globomycin analogs differing in the length of the fatty acid tail ${ }^{65}$

\begin{tabular}{ccccc}
\hline & \multicolumn{4}{c}{ MIC $(\mu \mathrm{g} / \mathrm{mL})$ against $S$. aureus strains } \\
\cline { 2 - 5 } $\begin{array}{c}\text { Globomycin } \\
\text { analog }\end{array}$ & SANK & SANK & SANK & SANK \\
& 70668 & 71790 & (MRSA) & 71990 \\
\hline$n=3, \mathbf{2 4}$ & $>100$ & $>100$ & $>100$ & $>100$ \\
$n=5, \mathbf{2 9}$ & 50 & 50 & 50 & 100 \\
$n=7, \mathbf{3 0}$ & 6.25 & 6.25 & 12.5 & 12.5 \\
\hline
\end{tabular}




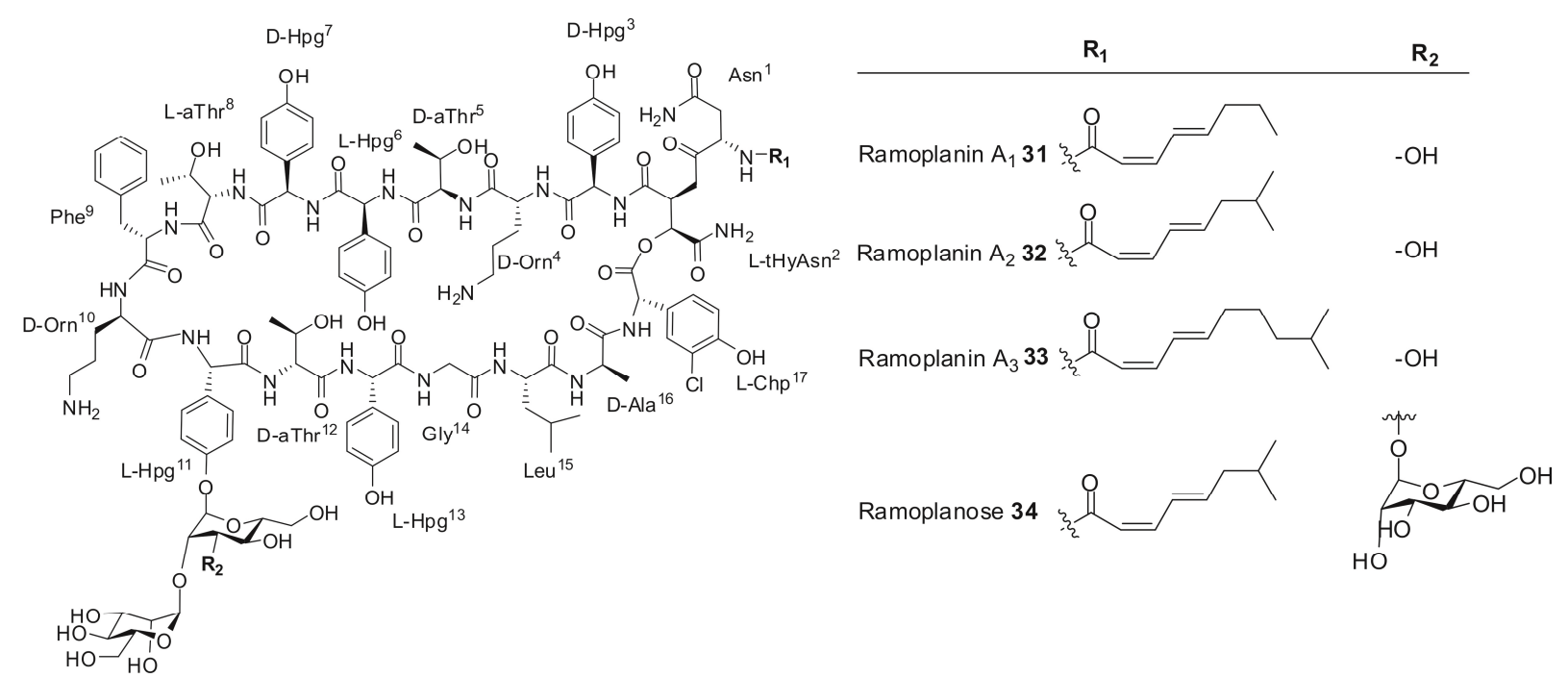

Figure 5. Structures of ramoplanins A1-A3 31-33 and ramoplanose 34.

cidal activity. ${ }^{65,66}$ This group of natural products is a rare example of antimicrobial agents active against both Gram-positive and Gram-negative bacteria, representing particularly interesting lead structure(s) for the development of novel broad-spectrum antibiotics.

\section{RAMOPLANINS/ENDURACIDINS}

In 1984 a research group from Gruppo Lepetit (Biosearch Italia) isolated from a culture broth of Actinoplanes sp. ATCC 33076 an antibiotic complex named A16686 , later renamed to ramoplanin, Figure 5. The isolated antibiotic complex was a mixture of three structurally similar compounds designated as A1-A3 31-33, out of which A2 32 represented the major component. ${ }^{67}$ Initial studies, including chemical degradation, mass spectrometry and 2D NMR experiments, revealed the structural complexity of these antibiotics. ${ }^{68,69}$ Isolated compounds were identified to be cyclic lipoglycodepsipeptides containing 17 amino acids, including several nonproteinogenic amino acids such as L-hydroxyphenylglycine (L-Hpg), D- and L- $a$ Thr, L-threo- $\beta$-hydroxyasparagine (L-tHyAsn), D-ornithine (D-Orn) and L-3chloro-4-hydroxyphenylglycine (L-Chp). The macrocycle is formed via lactone linkage between the L-Chp ${ }^{17}$ carboxyl group and the L- $t$ HyAsn ${ }^{2} \beta$-hydroxyl group. The latter one is also linked to $\mathrm{Asn}^{1}$ bearing an unusual unsaturated acyl chain on its N-terminus. In addition, $\mathrm{L}-\mathrm{Hpg}^{11}$ residue carries a disaccharide moiety, $\alpha-1,2$ dimannose, attached to its hydroxyl group. The amino acid sequence within the ramoplanin family of natural products is conserved; the only difference lies in the unsaturated acyl chain, Figure 5. The stereochemistry of ramoplanin's acyl chain was initially assigned to be $(2 Z, 4 Z) .{ }^{68}$ However, this was subsequently reexamined and corrected to $(2 Z, 4 E))^{70,71}$ Ramoplanins are structurally similar to ramoplanose $\mathbf{3 4}$, a trimannosylated ramoplanin isolated also from Actinoplanes sp. ${ }^{72}$ and to enduracidins. Enduracidins A 35 and B 36, Figure 6, were isolated in 1968 from Streptomyces fungicides

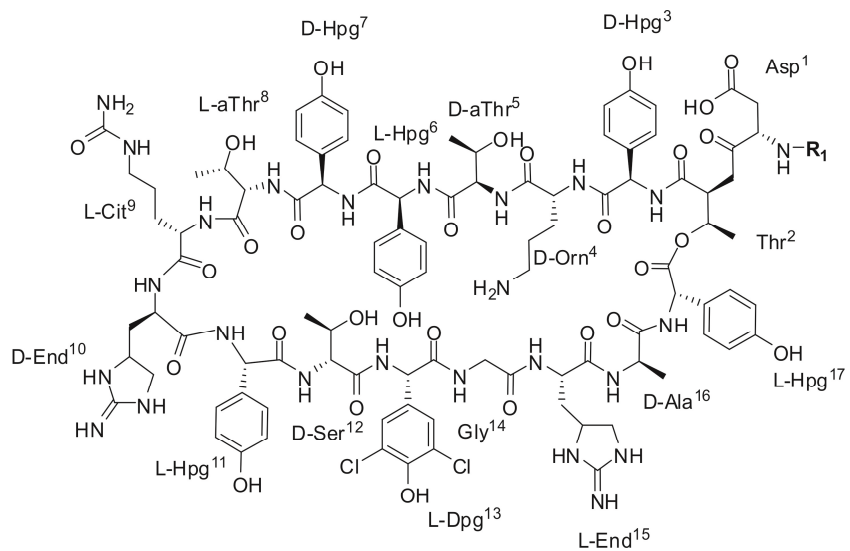

Figure 6. Enduracidins A 35 and B 36.

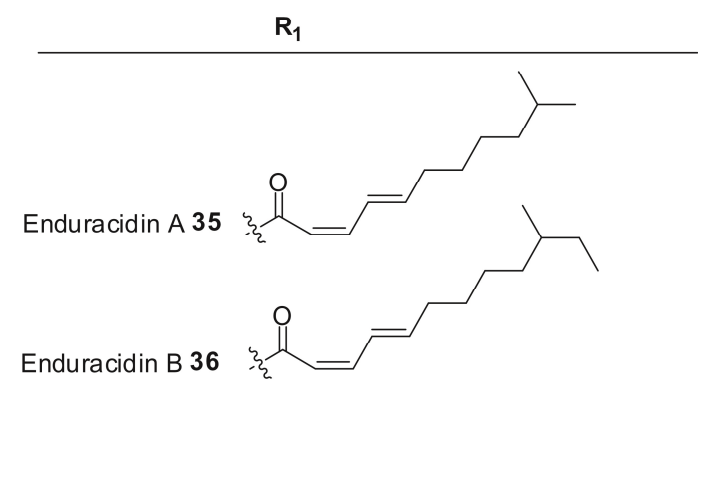


B5477 culture broth. ${ }^{73,74}$ Enduracidins A and B differ only in the length of the lipid tail. Enduracidins are 17mer peptides forming a macrocyclic core composed of 16-amino acids cyclized via lactone bridge between $\mathrm{Thr}^{2}$ and L-Hpg ${ }^{17}$ residues, Figure 6. The characteristic features of enduracidins are the amino acids D- and Lenduracididine (D-, L-End), L-citrulline (L-Cit), and L3,5-dichloro-4-hydroxyphenylglycine (L-Dpg). Enduracidin and ramoplanin share a number of structural similarities; however, enduracidins do not have a sugar moiety. These common structural features indicate a possible similarity in mode of action and a common active pharmacophore. ${ }^{75}$ The $3 \mathrm{D}$ NMR structure of ramoplanose revealed a double-stranded antiparallel $\beta$ sheet with seven intramolecular hydrogen bonds and two reverse turns. ${ }^{72}$ Almost identical structural characteristics were found in ramoplanin A2. In 1996 Kurtz and Guba determined the 3D structure of ramoplanin A2 32 in aqueous solution from multidimensional NMR experiments. The structure is characterized by two antiparallel $\beta$-sheets connected with six intramolecular hydrogen bonds and one reverse $\beta$-turn. ${ }^{70}$ Quite interestingly, Walker et al. ${ }^{76}$ showed that ramoplanin A2 in methanol forms a symmetric dimer at the interface of amino acid residues 10-14, and is stabilized with four intermolecular hydrogen bonds. In 2009 McCafferty et al. reported the first X-ray structure of ramoplanin A2, showing that ramoplanin $\mathrm{A} 2$ in the crystal forms an amphiphatic dimer with $C_{2}$ symmetry. This mutual orientation of monomers allows formation of a four-stranded antiparallel $\beta$-sheet, whose interface consists of amino acid residues $9-15$ and six intermolecular hydrogen bonds. ${ }^{77}$ The fact that ramoplanin A2 forms dimers in a hydrophobic solvent that mimics the environment at the bacterial cell surface and in the crystal may indicate the manner in which this antibiotic interacts with its bacterial target.

As expected, due to partial amino acid sequence comparability, the overall backbone structure of enduracidin and ramoplanin share a high degree of similarity. ${ }^{78}$ Enduracidin's structure is characterized by two antiparallel $\beta$-sheets that include residues 5-7 and $10-12$ connected by a turn composed of the residues 8 and 9 . Three hydrogen-bonding interactions stabilizing this $\beta$ hairpin arrangement are between residues D- $a \mathrm{Thr}^{5}$ and D-Ser ${ }^{12}, \mathrm{D}-\mathrm{Hpg}^{7}$ and D-End ${ }^{10}$, and D-Hpg ${ }^{7}$ and L-Cit ${ }^{9}{ }^{78}$

Ramoplanins A1-A3 31-33 possess identical antibiotic activities, and are active against Gram-positive bacteria, including resistant strains such as VRE and MRSA with MICs below $1 \mu \mathrm{g} / \mathrm{mL}^{79-83}$ They have a similar spectrum of antibacterial activities as vancomycin, but they are $4-8$ times more potent. ${ }^{84}$ In addition, ramoplanin A2 32 exhibits bactericidal activity at concentrations close to MICs for most Gram-positive bacteria, and at concentrations twice the MIC value against
VRE, while vancomycin only displays bacteriostatic activity at its MICs. ${ }^{82,85}$ Ramoplanins A1-A3 exhibit no activity against Gram-negative bacteria. ${ }^{84,86}$ Soon afterward, three other ramoplanin analogs were isolated from the culture broth of the producing microorganism and designated as A1'-A3', differing from A1-A3 in the $\alpha$ glycosidic moiety. Ramoplanins A1'-A3' contain only a monosaccharide unit. $^{87}$ Interestingly, A2' showed better activity against certain bacterial strains than A2; otherwise, their antimicrobial activities are similar. ${ }^{87}$ Enduracidins exhibited a similar spectrum of antibacterial activities to ramoplanins, whereas no data for ramoplanose antibacterial activity was reported.

SAR studies were performed by several groups in order to determine important structural characteristics modulating antibacterial activity. Ciabatti et al. prepared deglycosylated ramoplanin analogs, and analogs containing saturated $\mathrm{N}$-terminal fatty acid chains. ${ }^{68}$ These modifications had no significant effect on ramoplanin's antibacterial activity. McCafferty et al. had also reported synthesis of several semi-synthetic ramoplanin analogs with modifications on the $\mathrm{D}-\mathrm{Orn}^{4}$ and $\mathrm{D}-\mathrm{Orn}^{10}$ side chains. ${ }^{75}$ Guanidylation or reductive amination of the Orn residues had minimal to moderate effects on ramoplanin's antimicrobial activity. In contrast, loss of the cationic charge by Orn acetylation, and hydrolysis of the lactone linkage severely diminished or fully deleted depsipeptide's activity. ${ }^{75,88,89}$ Total solution-phase syntheses of ramoplanin A2, ramoplanose aglycon, and ramoplanin A1-A3 aglycons, were accomplished by Boger et al. ${ }^{71,88-90}$ The retrosynthetic analysis was designed around ramoplanin A2 3D structure in solution. Based on this analysis, three linear peptide precursors (heptapeptide composed of residues 3-9, pentadepsipeptide composed of residues 1,2 and 15-17, and pentapeptide composed of residues 10-14) were prepared, sequentially coupled and cyclized to yield the ramoplanin aglycon macrocyclic core. The coupling sites were chosen to maximize the efficacy of the synthesis, prevent potential racemization that may occur during the final macrocyclization step, and to promote formation of a $\beta$-sheet secondary structure of the linear 17-aminoacid precursor that would facilitate the final macrocyclization step. Ramoplanin A1 and A3 aglycons were prepared by acylation introduction of the lipid sidechains onto the synthetic ramoplanin macrocyclic core. $^{91}$ In order to provide a more chemically stable alternative to natural ramoplanin A2, two amide aglycon analogs have been synthesized where L- $t$ HyAsn ${ }^{2}$ has been replaced by L-2,3-diaminopropionic acid (L-Dap) or L-2,4-diaminobutyric acid (L-Dab). ${ }^{92}$ The L-Dapanalog maintained the same activity as ramoplanin A2, whereas the ring extension by one methylene group, LDab-analog, led to a loss of antibiotic activity. Recently, Boger et al. reported an alanine-scan on ramoplanin's 


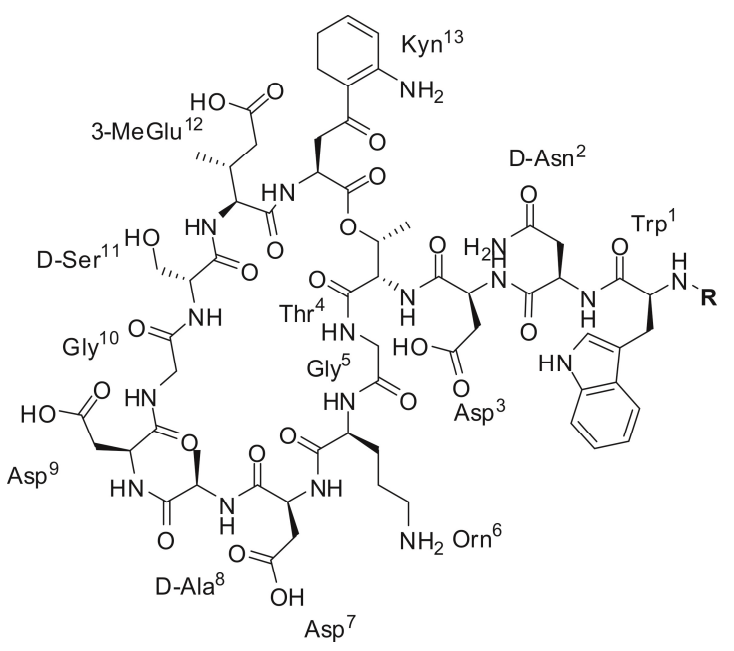

Figure 7. Structures of daptomycin 37 and $A 21978 C_{1}-C_{3} \mathbf{3 8}-\mathbf{4 0}$.

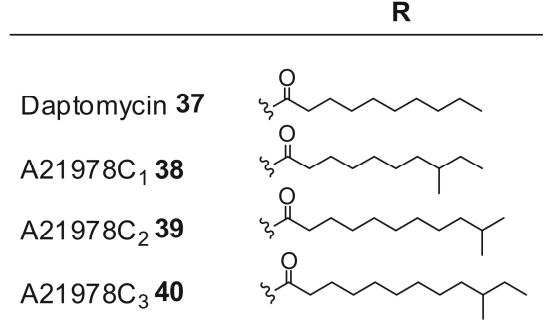

L-Dap-analogue providing insight into the potential role and importance of each amino acid residue for its antibacterial activity. ${ }^{93}$ In contrast, there are no reports on the total synthesis of enduracidins. However, biosynthesis of enduracidin A $\mathbf{3 6}$ analogs with altered halogenation patterns has been reported in 2010, and initial in vitro antibacterial evaluation showed that these analogs retained activity against $S$. aureus. $^{94}$

In 1990 Somner and Reynolds showed that ramoplanin blocks bacterial cell wall biosynthesis at the step catalyzed by membrane-associated glycosyltrensferase MurG. ${ }^{95}$ They proposed a mechanism of action that involves ramoplanin binding to MurG substrate Lipid I and inhibition of Lipid II formation. Eight years later, Brötz, et al. showed that ramoplanin, as well as some lantibiotics, interacted with Lipid II, and raised a question of a possible second mode of action for ramoplanin. ${ }^{96}$ Recently Walker et al. demonstrated that ramoplanin has higher affinity for Lipid II, and proposed the transglycosylation step as the primary target. Inhibition kinetic experiments revealed that ramoplanin binds Lipid II with a stoichiometry of $2: 1 .^{97}$ Interestingly, fibril formation of Lipid II analogs was observed upon titration with ramoplanin. ${ }^{75,98}$ Walker's group also found that ramoplanin inhibits MurG by the mechanism that does not include binding to Lipid I, but rather via direct interaction with the enzyme. ${ }^{99}$ However, since Lipid I and MurG are intracellular, and therefore not accessible to ramoplanin, ${ }^{98,100}$ and considering ramoplanin's higher affinity toward Lipid II, it is not clear whether inhibition of MurG is of physiological relevance. Enduracidin has an almost identical mode of action as ramoplanin. ${ }^{97}$ The main difference is in the MurG inhibition. Ramoplanin displayed noncompetitive inhibition of MurG, whereas enduracidin produced an inhibition curve consistent with substrate binding. ${ }^{97}$ Ramoplanin is currently in Phase II trial for the treatment of Clostridium difficile associated diseases (CDAD), and in Phase III development for the prevention of vancomycin-resistant enterococci bloodstream infections. Enduracidin has been shown to be effective in humans for treating urinary tract and skin infections caused by methicillin-resistant S. aureus. ${ }^{101}$ No toxicity or side effects for enduracidin in these trials were reported.

\section{DAPTOMYCIN}

In the early 1980s, a group at Lilly Research Laboratories isolated a series of novel antibiotics designated as A21978A, B, C, D and E from Streptomyces roseosporus NRRL 11379 culture broth, Figure 7. ${ }^{102}$ The major component, A21978C, was highly active against Grampositive bacteria. $^{103}$ RP HPLC analysis of A21978C showed the presence of six compounds $\left(\mathrm{C}_{0}-\mathrm{C}_{5}\right)$, out of which three compounds were most abundant, $\mathrm{A} 21978 \mathrm{C}_{1}-\mathrm{C}_{3}$ 38-40. Structural analysis revealed all compounds to be cyclic lipodepsipeptides comprised of 13 amino acid residues, 5 of which were unusual amino acids, including L-ornithine (L-Orn), L-threo-3methylglutamic acid (L-3-MeGlu), L-kynurenine (LKyn) and two D-amino acid residues. Initially, $\mathrm{Asn}^{2}$ configuration was assigned as $\mathrm{L}$, and recently this assignation was corrected to a D-configuration. ${ }^{104}$ Ten amino acids form the depsipeptide macrocyclic core with a lactone linkage between the L-Kyn ${ }^{13}$ carboxyl group and the $\mathrm{Thr}^{4}$ hydroxyl group. The remaining tripeptide, $\mathrm{Asp}^{3}-\mathrm{Asn}^{2}-\mathrm{Trp}^{1}$, is attached to the $\mathrm{Thr}^{4}$ carboxyl group. The amino acid sequence is conserved in all six $\mathrm{C}_{0}-\mathrm{C}_{5}$ daptomycins. The structural differences lie in the fatty acid chain attached to the $\operatorname{Trp}^{1}$ amino group. In the compounds $\mathrm{C}_{1}-\mathrm{C}_{3} \mathbf{3 8}-\mathbf{4 0}$, the fatty acid chain was found to be anteiso-undecanoyl, iso-dodecanoyl and anteiso-tridecanoyl. A minor compound of the complex $\mathrm{C}_{0}$, was found to have a mixture of both linear and 
branched decanoyl, while $\mathrm{C}_{4}$ and $\mathrm{C}_{5}$ both contain dodecanoyl fatty acids. ${ }^{105}$ Daptomycin 37 , a member of the A21978C complex, contains a straight $\mathrm{C}_{10}$ lipid sidechain, Figure 7.

Comparison of $\mathrm{A}_{2} 1978 \mathrm{C}_{1}$ activity with those of vancomycin, teichomycin and several $\beta$-lactam antibiotics, showed that $\mathrm{A}_{2} 1978 \mathrm{C}_{1}$ was at least as active as vancomycin against all streptococci and staphylococci tested, including MRSA and penicillin-resistant pneumococci. ${ }^{106}$ It was also found to be bactericidal against enterococci at concentrations close to MICs $(2 \mu \mathrm{g} / \mathrm{mL})$. When combined with gentamycin, a bactericidal synergism was observed by time-kill methods. ${ }^{106}$ A21978C $C_{1}$ did not interact with penicillin-binding proteins of bacterial cell membranes nor did it interfere with the DNA, RNA or protein synthesis. However, it inhibited peptidoglycan biosynthesis of both S. faecalis and S. aureus. Even more interesting was the finding that activity of this family of naturally occurring antibiotics strongly depends on the concentration of $\mathrm{Ca}^{2+}$ in the culture medium, whereas no increase in activity was observed if medium is supplemented with $\mathrm{Mg}^{2+}, \mathrm{Zn}^{2+}$ or $\mathrm{Ba}^{2+} \cdot 106$ A21978C's maximum antibacterial potency is reached at the $\mathrm{Ca}^{2+}$ concentration of $50 \mathrm{mg} / \mathrm{L}(1.25 \mathrm{mM})$; the concentration of ionized calcium normally found in human serum. ${ }^{107}$ It has also been shown that these antibiotics cause potassium release from $S$. aureus, suggesting that their bacterial target is membrane and/or cell wall. ${ }^{108,109}$ This behavior is similar to one of calciumdependent antibiotic (CDA) which forms ionconducting channels in planar phospholipid membranes. ${ }^{110}$ The activity of A21978C antibiotics was proposed to be very complex, depending on incorporation of the antibiotic into bacterial membrane. Studies performed by Lakey et al. and recently by Jung et al. on daptomycins' interaction with phospholipid vesicles and $\mathrm{Ca}^{2+}$, suggested that charge neutralization through $\mathrm{Ca}^{2+}$ complexation facilitates penetration of the peptide into the membrane. ${ }^{111,112}$ It was found that the extent of penetration into the lipid bilayer is inversely proportional to the side chain length, indicating that $\mathrm{Ca}^{2+}$ dependent interaction is a specific interaction involving the polar head groups of the phospholipids and the daptomycins, with the role of the lipidic side chain being most important for the initial antibiotic attachment to the membrane. However, the length of the side chain was shown to influence the peptide's toxicity. Peptides bearing longer side-chain fatty acids exhibited higher toxicity. The optimal balance between toxicity and antimicrobial activity was obtained with daptomycin, an A21978C derivative containing a decanoyl chain. ${ }^{113,114}$ In 1988 Huber et al. reported large quantity production of desired daptomycin by supplying decanoic acid during $S$. roseosporus fermentation. ${ }^{115}$ The lack of suitable solution or solid-phase synthetic approaches toward dapto- mycin and its analogs makes chemoenzymatic methods important alternatives to generate and scale up daptomycin derivatives for antibacterial screening and drug development. Chemoenzymatic methods usually combine standard solid-phase peptide synthesis (SPPS) with enzymatic peptide cyclization mediated through excised thioesterase (TE) domains from NRPSs. ${ }^{116-118}$ Antibacterial activity studies of chemoenzymatically synthesized daptomycin derivatives revealed that four amino acids, Asp ${ }^{7}, \mathrm{Asp}^{9}$, and L-3-MeGlu ${ }^{12}$ and L-Kyn ${ }^{13}$, are important for the peptide's antibacterial potency. Furthermore, derivatives containing different macrocyclic core size were prepared by shifting the $\mathrm{Thr}^{4}$ residue to position 3, 5 or 6 in the linear precursor generating 8,9 and 11-membered rings. ${ }^{118}$ Genetic engineering of the NRPS in the daptomycin biosynthesis was further exploited for combinatorial biosynthesis of novel antibiotics. Baltz et al. combined NRPS module exchanges, NRPS subunit exchanges, inactivation of the tailoring enzyme glutamic acid 3-methyltransferase, and natural variation of the lipid tail to generate a library of daptomycin analogs. ${ }^{104,119,120}$ These bioengineered daptomycin analogs include modifications at the L-Kyn ${ }^{13}$ position, and modifications of the daptomycin macrocyclic core at residues that are not conserved among structurally related lipopeptides. Some of these analogs were as active as daptomycin, demonstrating that the combinatorial biosynthesis is an effective tool to generate daptomycin analogs with significant structural diversity for further clinical evaluation.

A semisynthetic method was also successfully applied to modify the daptomycin amino acid core. In an attempt to enhance the potency of daptomycin, Parr et al. synthesized a series of $\mathrm{N}$-acylated L-Orn ${ }^{6}$ analogs using activated esters, anhydrides, and guanidinylating reagents. ${ }^{121}$ Based on the MIC data, it was shown that the $\mathrm{Orn}^{6}$ amino group is not essential for daptomycin's antibacterial activity. Some analogs maintaining a free amine in the Orn region showed similar or slightly better antibacterial activity, and significantly different pharmacokinetic profiles than daptomycin.

Although it is well established that daptomycin exerts its mode of action on the bacterial cell membrane in Gram-positive bacteria, its precise mode of action has not been completely clarified. Initially, Allen et al. have shown that daptomycin has a disruptive effect on membrane permeability as demonstrated by the loss of intracellular potassium upon bacteria exposure to the peptide. The fact that this antibiotic inhibited incorporation of $\left[{ }^{14} \mathrm{C}\right]$ alanine and $\left[{ }^{14} \mathrm{C}\right] \mathrm{DAP}$ into the peptidoglycan of S. aureus and Bacillus megaterium, and the lack of any significant inhibition of protein, RNA, DNA or lipid biosynthesis indicated that the membrane is not likely a lethal target for this antibiotic. Instead, they suggested that daptomycin inhibits formation of peptidoglycan 
precursor, UDP-MurNAc-pentapeptide. ${ }^{122}$ Silverman et al. proposed a multistep mode of action for daptomycin. ${ }^{109}$ According to the proposed mechanism, in the first step, daptomycin binds weakly to the cytoplasmic membrane and complex $\mathrm{Ca}^{2+}$. This causes conformational change, and leads to daptomycin's insertion into the plasma membrane and its subsequent oligomerization. In the second step, daptomycin oligomers form a channel through which intracellular potassium ion is lost, leading to membrane depolarization and bacterial cell death. Recently, a more complex mode of action was proposed for daptomycin. In 2004 Hancock et al. suggested that the bactericidal action of daptomycin is not exclusively a result of the membrane depolarization, but rather daptomycin's interaction with several bacterial components such as cell wall, various enzymes, RNA and DNA. ${ }^{112}$ Chopra et al. in 2008 re-examined the daptomycin mode of action proposed by Silverman et $a l$. by performing more detailed experiments on kinetics of membrane depolarization and loss of $\mathrm{K}^{+}, \mathrm{Mg}^{2+}$, and ATP. ${ }^{123}$ Obtained experimental data showed that daptomycin-induced efflux of $\mathrm{Mg}^{2+}$, and ATP occurs in conjunction with $\mathrm{K}^{+}$leakage. Based on these findings, Chopra et al. proposed that the bactericidal activity of daptomycin is not simply a consequence of $\mathrm{K}^{+}$efflux and probably involves more general disruption of the membrane.

Although Eli Lilly and Co. began development of daptomycin in 1985, they later abandoned further pursuit due to Phase II clinical trial results which showed the occurrence of potential drug-induced myopathic events. ${ }^{124}$ In 1997 Cubist Pharmaceuticals Inc. licensed daptomycin and re-instigated clinical development of the drug. To determine the dosing regimen with potentially lower muscle toxicity two studies were conducted with dogs. Repeated intravenous administration every $24 \mathrm{~h}$ versus every $8 \mathrm{~h}$ for 20 days indicated that oncedaily administration appeared to have minimized potential for daptomycin-induced skeletal-muscle effects. ${ }^{125}$ Further clinical trials were conducted using a single daily dose of the antibiotic. Daptomycin was approved in the United States in 2003 for treatment of complicated skin and skin structure infections associated with methicillin-susceptible $S$. aureus (MSSA), MRSA, $S$. pyogenes, Streptococcus agalactiae, Streptococcus dysgalactiae subsp. equisimilis and E. faecalis (vancomycin-susceptible only) and in 2006 for treatment of bacteraemia and right-sided endocarditis caused by MSSA and MRSA. ${ }^{126,127}$ Also, it was approved in Europe in 2006 for treatment of complicated skin and soft tissue infections. Daptomycin is marketed under the trade name Cubicin.

Although daptomycin exhibits strong activity against variety of Gram-positive bacteria including $S$. pneumoniae, the experimental and clinical data for mice

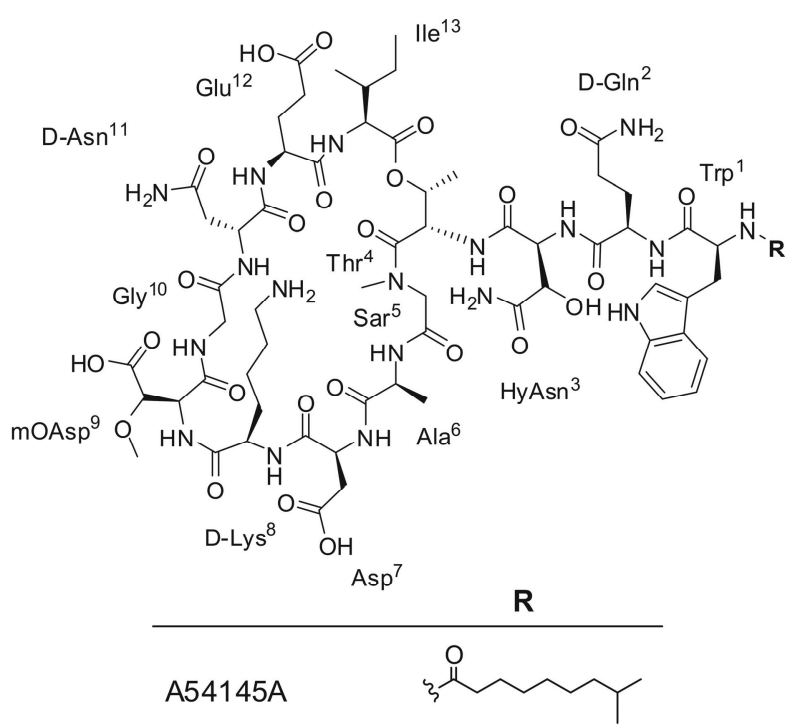

Figure 8. Representative member of the A54145 family, A54145A.

and humans showed that daptomycin lacks efficacy against Gram-positive bacterial infections of the lung. ${ }^{128}$ In phase III clinical trial for the treatment of patients with community-acquired pneumonia (CAP) daptomycin (applied at a dose of $4 \mathrm{mg} / \mathrm{kg}$ ) failed to achieve superiority over ceftriaxone, a drug of choice for the treatment of CAP. Reported efficacies for daptomycin and ceftriaxone are $79 \%$ and $87 \%$, respectively. ${ }^{128}$ Daptomycin's poor efficacy against CAP may be attributed to its interaction with pulmonary surfactant components. ${ }^{129}$ Recent attempts to generate more potent daptomycin derivatives in the presence of bovine surfactant utilize combinatorial biosynthesis approach. ${ }^{130}$

A5415 is a complex of eight cyclic lipodepsipeptide antibiotics produced by Streptomyces fradiae and structurally similar to daptomycin, Figure $8 .{ }^{131-134}$ These antibiotics exhibited potent activity against $S$. aureus and $S$. pyogenes infections in mice. However, acute mouse toxicities hampered their further development as a novel drug. ${ }^{135}$ Some of these antibiotics were shown to be much less inhibited by bovine surfactant than daptomycin, providing therefore a lead structure for modifications to explore structure-activity relationship (SAR) around A5415. Very recently, Baltz et al. reported preparation of several A5415 analogs by modifying the A5415 NRPS using segments of the daptomycin NRPS genes. ${ }^{136-138}$ Three mutants defective in IptJ, IptK or IptL genes encoding the enzymes involved in biosynthesis of hydroxy-Asn ${ }^{3}$ and methoxy-Asp ${ }^{9}$ were generated. These deletions were combined with deletion of the IptI gene involved in biosynthesis of 3-methyl-Glu ${ }^{12}$ and with the plasmid containing combination of Ipt genes to produce a series of novel A5415/daptomycin analogs. For all the compounds, removal of the methoxy group 


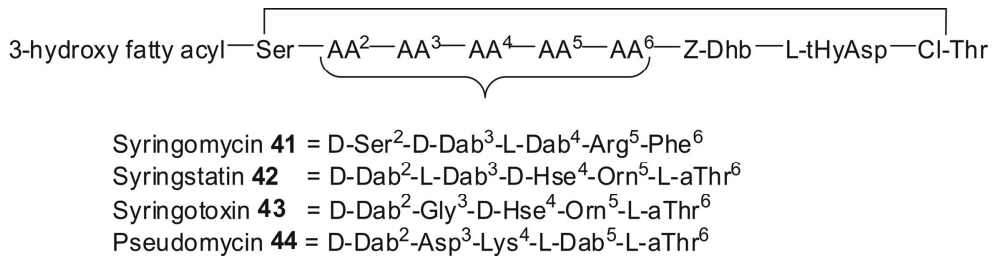

Figure 9. Representative lipodepsinonapeptides from Pseudomonas sp.

from $\mathrm{Asp}^{9}$ and the hydroxy group from $\mathrm{Asn}^{3}$ yielded compound A5415( Asn $^{3} \mathrm{Asp}^{9}$ ) with comparable antibacterial activity to the parent A5415 or daptomycin, and without loss in activity in the presence of bovine surfactant. ${ }^{137}$ The structure of A5415( $\left.\mathrm{Asn}^{3} \mathrm{Asp}^{9}\right)$ predicted from the genetic changes and bioinformatics studies was confirmed by chemical transformations, amino acid quantitation by enantiomer labeling, LC-MS/MS and 2D NMR techniques. ${ }^{138}$ This approach creates new possibilities for daptomycin SAR, and discovery of new and more potent antibiotics of this class.

\section{OTHER LIPODEPSIPEPTIDES PRODUCED BY Pseudomonas spp.}

Plant pathogenic bacteria Pseudomonas spp. produce a variety of biologically active compounds, including nonribosomally synthesized cyclic lipodepsipeptide phytotoxins. Different ecotypes of Pseudomonas syringae pv. syringae produce structurally closely related lipodepsipeptides such as syringomycins 41, syringostatins 42 and syringotoxin 43, Figure 9. ${ }^{139-146}$ Another structurally similar compound, pseudomycin 44, was isolated from $P$. syringae MSU $16 \mathrm{H}$, a bacterium proposed for the biocontrol of the causal agent of the highly destructive Dutch elm disease, Figure 9. ${ }^{147}$ The structural similarities among these lipodepsipeptides initiated efforts to investigate their biosynthetic pathways and their biological activities. All these lipopeptide phytotoxins contain a polar cyclic nonapeptide head and an unbranched 3-hydroxy fatty acid side chain of different lengths, Figure 9. The four lipodepsipeptides have a common C-terminal sequence consisting of $Z$ dehydrobutyric acid (Z-Dhb), L- $t$ HyAsp, and L- $\gamma$ chlorothreonine (L-Cl-Thr). The greatest differences are in the amino acid sequences between positions 2 and 6 . Besides proteinogenic amino acids, peptide sequence in these positions also contains residues such as D-Ser, L$a$ Thr, D- and L-2,4-diaminobutyric acid (D- or L-Dab), and D-homoserine (D-Hse). A macrocyclic ring is formed by a lactone linkage between the Ser $^{1}$ side chain hydroxyl group and the Cl-Thr ${ }^{9}$ carboxyl group. Similar to the previous cases, these lipodepsipeptide phytotoxins are synthesized nonribosomally by $470 \mathrm{kDa}$ or larger NRPSs. ${ }^{148,149}$ To our knowledge, there are no reports on their total synthesis or of the preparation of synthetic or bioengineered analogs. All lipodepsipeptides show similar phytotoxicity. ${ }^{139,147,150}$ Lipid bilayer studies showed that the probable mode of action involves insertion onto the target plant plasma membrane with formation of ion channels, causing ion flux and cell death. ${ }^{151}$

Syringopeptins are another interesting group of lipodepsipeptides produced by $P$. syringae $\mathrm{pv}$. syringae. ${ }^{152}$ They share many of the structural features of previously discovered lipodepsinonapeptides, Figure $10{ }^{153}$ Syringopeptins are composed of 22 or 25 amino acid residues. Eight residues form the macrocyclic depsipeptide core to which a peptidyl chain containing 3hydroxy fatty acid is attached. Interestingly, the amino acid sequence varies with syringopeptins producing $P$. syringae pv. syringae strains isolated from different sources. ${ }^{152-155}$ Like other lipodepsinonapeptides from this group, they contain several nonproteinogenic amino acids, including L-Dab, L-Dhb, L- $a$ Thr, in addition to Dand L-amino acids. In fact, most of the residues in the peptidyl chain are of D-configuration. ${ }^{153}$ The fatty acid tail can be either decanoic or dodecanoic acid. ${ }^{152}$ Hutchison and Gross suggested that syringopeptin and related lipodepsipeptide syringomycin aggregation is required for pore forming in lipid bilayers. ${ }^{150} \mathrm{In}$ addition

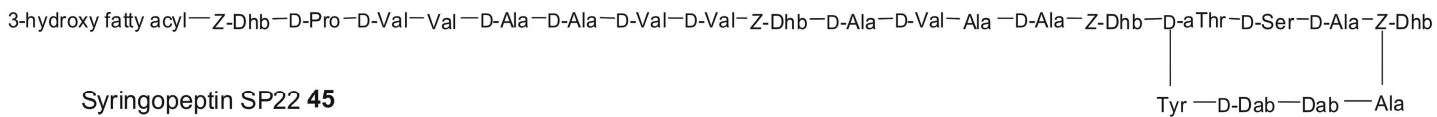

3-hydroxy fatty acyl-Z-Dhb-D-Pro-D-Val-Ala-D-Ala-Val-D-Leu-D-Ala-D-Ala-Z-Dhb-D-Val-Z-Dhb-D-Ala-D-Val-D-Ala-D-Ala-Z-Dhb-D-aThr-D-Ser-D-Ala-Va Syringopeptin SP25 46

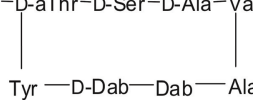

Figure 10. Representative syringopeptins SP 22-A 45 and SP 25-A 46. 
to their phytotoxic activity, syringopeptins exhibit noticeable antibiotic properties as well. ${ }^{156-158}$ Syringopeptins are active against Gram-positive bacteria such as $B$. megaterium, S. aureus, S. pyogenes, and Mycobacterium smegmatis with $0.98-7.8 \mu \mathrm{g} / \mathrm{mL}$ MIC range. ${ }^{156-158}$ These lipodepsipeptides are not active against Gramnegative bacteria. The most probable antibacterial mode of action involves pore formation in the host membrane leading to cytolysis. ${ }^{139,150,151}$ Takemoto et al. suggested that the cell wall anionic teichoic acids modulate syringopeptin action and promote selective activity against Gram-positive bacteria such as Bacillus subtilis. However, the molecular basis for their antibacterial activities is not yet completely elucidated. Besides antibacterial activity, all lipodepsipeptides inhibit the growth of fungi. The antifungal activity also involves the lipid bilayer membrane, but the activities are affected by membrane composition, especially by sphingolipids and sterols. ${ }^{156,159-162}$ Lipodepsipeptide phytotoxins have also been proven to induce human and rabbit red blood cell lysis. ${ }^{150,156,159,163-165}$ These amphipathic compounds insert themselves into the membrane bilayer and form pores, causing efflux of $\mathrm{H}^{+}, \mathrm{K}^{+}$and $\mathrm{Ca}^{2+}$ and cell death. ${ }^{165-170}$ Taking into consideration the potent antifungal activity of these lipodepsipeptides and due to high human and animal red blood cell toxicity, their potential future development may be rather directed toward agricultural applications.

\section{SUMMARY}

Occurrence of multidrug-resistant pathogens and urgent demands for new and more potent antimicrobials place this class of natural products in the center of attention for development of new antibacterial agents. Some of those compounds, such as cyclic lipodepsipeptide daptomycin 37, Figure 7, (Cubicin, Cubist Pharmaceuticals, Inc.) are already approved in the USA, European Union and Canada for the treatment of bloodstream and complicated skin infections caused by multidrug-resistant bacterial strains. Ramoplanin A2 32 (Oscient Pharmaceuticals Corporation) is another good example of cyclic depsipeptide potential in the development of new antibiotics, Figure 5. Ramoplanin is currently in a Phase II trial for the treatment of $C$. difficile-associated diarrhea (CDAD) and in Phase III development for the prevention of vancomycin-resistant enterococci bloodstream infections. Despite the progress in development of new antibacterial agents, it is inevitable that resistant strains of bacteria will emerge in response to widespread use of a particular antibiotic and limit its usefulness. Therefore, development of new antibiotics remains our most efficient way to combat multi-drug bacterial resistance.
Acknowledgements. We wish to acknowledge the support of cyclic lipodepsipeptide work described in this article by the NIH (1S06-GM073621-01) and AHA (0630175N) Grant to P.C. We also would like to thank our colleague Dr. Mare Cudic for the helpful comments, and Ms. Karen Gottwald for editing the text.

\section{REFERENCES}

1. S. Grabley and R. Thiericke, Drug discovery from nature, Springer-Verlag, Heidelberg, 1999

2. D. J. Newman, G. M. Cragg, and K. M. Snader, J. Nat. Prod. 66 (2003) 1022-1037.

3. G. M. Cragg, D. J. Newman, and K. M. Snader, J. Nat. Prod. 60 (1997) 52-60.

4. J. W. H. Li and J. C. Vederas, Science 325 (2009), 161-165.

5. D. J. Newman and G. M. Cragg, J. Nat. Prod. 70 (2007), 461-477.

6. A. L. Harvey, Drug Discov. Today 13 (2008), 894-901.

7. Y.-W. Chin, M. Balunas, H. Chai, and A. Kinghorn, AAPS J. 8 (2006) E239-E253.

8. M. Ayoub and D. Scheidegger, Chimica Oggi 24 (2006) 46-48.

9. P. Vlieghe, V. Lisowski, J. Martinez, and M. Khrestchatisky, Drug Discovery Today 15 (2010) 40-56.

10. T. Vorherr, Chim. Oggi. 28 (2010) 22-25.

11. D. Kumar Malik, S. Baboota, A. Ahuja, S. Hasan, and J. Ali, Curr. Drug Delivery 4 (2007) 141-151.

12. C. Adessi and C. Soto, Curr. Med. Chem. 9 (2002) 963.

13. N. Sewald and H.-D. Jakubke, Peptides: Chemistry and Biology, $2^{\text {nd }}$ Ed., Wiley-VCH Verlag GmbH\&Co: Weinheim, 2009.

14. J. S. Davies, J. Pept. Sci. 9 (2003) 471-501.

15. J. N. Lambert, J. P. Mitchell, and K. D. Roberts, J. Chem. Soc. Perkin. Trans. 1 (2001) 471-484.

16. L. Peng and P. P. Roller, Curr. Top. Med. Chem. 2 (2002) 325.

17. C. Blackburn and S. A. Kates, Solid-phase synthesis of cyclic homodetic peptides, in: B. F. Gregg (Ed.), Methods in Enzymology, Academic Press, Vol. 289, 1997, pp. 175-198.

18. V. J. Hruby and B. G. Bonner, Methods in molecular biology 35 (1994) 201-240.

19. S. A. Kates, N. A. Sole, F. Albericio, and G. Barany, Solid-phase synthesis of cyclic peptides, in: C. Basava, G. N. Anantharamaiah (Eds): Peptides: Design, synthesis and biological activity, . Brikhauser: Boston, 1994, pp. 39-59.

20. M. M. Shemyakin, L. A. Shchukina, E. I. Vinogradova, G. A. Ravdel, Y. and A. Ovchinnikov, Cell. Mol. Life Sci. 22 (1966) 535-536.

21. N. H. Bramson, N. E. Thomas, and E. T. Kaiser, J. Biol. Chem. 260 (1985) 15452-15457.

22. O. Arad and M. Goodman, Biopolymers 29 (1990) 1633-1649.

23. G. S. Coombs, M. S. Rao, A. J. Olson, P. E. Dawson, and E. L. Madison, J. Biol. Chem. 274 (1999) 24074-24079.

24. M. A. Marahiel, J. Pept. Sci. 15 (2009) 799-807.

25. S. A. Sieber and M. A. Marahiel, J. Bacteriol. 185 (2003) 7036-7043.

26. J. Grunewald and M. A. Marahiel, Microbiol. Mol. Biol. Rev. 70 (2006) 121-146.

27. J. I. Shoji, H. Hinoo, K. Matsumoto, T. Hattori, T. Yoshida, S. Matsuura, and E. Kondo, J. Antibiot. 41 (1988) 713-718.

28. T. Kato, H. Hinoo, Y. Terui, J. K. Kikuchi, and J. I. Shoji, J. Antibiot. 41 1988, 719-725.

29. J. O'Sullivan, J. E. McCullough, A. Tymiak, D. R. Kirsch, and W. H. Trejo, J. Antibiot. 41 (1988) 1740-1744.

30. D. P. Bonner, J. O'Sullivan, K. S. Tanaka, J. M. Clark, and R. R. Whitney, J. Antibiot. 41 (1988) 1745-1751. 
31. A. A. Tymiak, T. J. McCormick, and S. E. Unger, J. Org. Chem. 54 (1989) 1149-1157.

32. T. Kato, H. Hinoo, Y. Terui, J. K. Kikuchi, and J. I. Shoji, J. Antibiot. 42 (1989) C-2.

33. G. G. Cardillo, L. Gentilucci, M. Gianotti, and A. Tolomelli, Eur. J. Org. Chem. 2000 (2000) 2489-2494.

34. S. Armaroli, G. Cardillo, L. Gentilucci, M. Gianotti, and A. Tolomelli, Org. Lett. 2 (2000) 1105-1107.

35. G. Cardillo, L. Gentilucci, A. Tolomelli, and C. Tomasini, Synlett 1999 (1999) 1727-1730.

36. C. Palomo, M. Oiarbide, I. Ganboa, and J. I. Miranda, Tetrahedron Lett. 42 (2001) 8955-8957.

37. C. Palomo, J. M. Aizpurua, I. Ganboa, B. Odriozola, E. Maneiro, J. I. Miranda, and R. Urchegui, Chem. Coтmun. 1996 161-162.

38. A. M. Hafez, T. Dudding, T. R. Wagerle, M. H. Shah, A. E. Taggi, and T. Lectka, J. Org. Chem. 68 (2003) 5819-5825.

39. B. J. Egner and M. Bradley, Tetrahedron 53 (1997) 14021-14030.

40. F. von Nussbaum, S. Anlauf, J. Benet-Buchholz, D. Häbich, J. Köbberling, L. Musza, J. Telser, H. Rübsamen-Waigmann, and N. A. Brunner, Angew. Chem. Int. Ed. 46 (2007) 2039-2042.

41. A. Guzman-Martinez, R. Lamer, and M. S. VanNieuwenhze, $J$. Am. Chem. Soc. 129 (2007) 6017-6021.

42. H. Maki, K. Miura, and Y. Yamano, Antimicrob. Agents Chemother. 45 (2001) 1823-1827.

43. J. I. Shoji, H. Hinoo, T. Katayama, K. Matsumoto, T. Tanimoto, T. Hattori, I. Higashiyama, H. Miwa, K. Motokawa, and T. Yoshida, J. Antibiot. 45 (1992) 817-823.

44. J. I. Shoji, H. Hinoo, T. Katayama, Y. Nakagawa, Y. Ikenishi, K. Iwatani, and T. Yoshida, J. Antibiot. 45 (1992) 824-831.

45. A. Wohlrab, R. Lamer, and M. S. VanNieuwenhze, J. Am. Chem. Soc. 129 (2007) 4175-4177.

46. K. Kurusu and K. Ohba, J. Antibiot. 40 (1987) 1506-1514.

47. Y. Kajimura and M. Kaneda, J. Antibiot. 49 (1996) 129-135.

48. Y. Kajimura and M. Kaneda, J. Antibiot. 50 (1997) 220-228.

49. J. Kuroda, T. Fukai, M. Konishi, J. Uno, K. Kurusu, and T. Nomura, Heterocycles 53 (2000) 1533-1549.

50. J. R. Cochrane, C. S. P. McErlean, and K. A. Jolliffe, Org. Lett. 12 (2010) 3394-3397.

51. P. H. Beatty and S. E. Jensen, Can. J. Microbiol. 48 (2002) 159-169.

52. M. Stawikowski and P. Cudic, Tetrahedron Lett. 47 (2006) 8587-8590.

53. J. Li, P. K. Beatty, S. Shah, and S. E. Jensen, Appl. Environ. Microbiol. 73 (2007) 3480-3489.

54. S.-K. Choi, S.-Y. Park, R. Kim, C.-H. Lee, J. F. Kim, and S.-H. Park, Biochem. Bioph. Res. Co. 365 (2008) 89-95.

55. S. Omoto, H. Suzuki, and S. Inouye, J. Antibiot. 32 (1979) 83-86.

56. S. Omoto, H. Ogino, and S. Inouye, J. Antibiot. 34 (1981) 1416-1423.

57. M. Inukai, M. Nakajima, M. Osawa, T. Haneishi, and M. Arai, $J$. Antibiot. 31 (1978) 421-425.

58. H. Kogen, T. Kiho, M. Nakayama, Y. Furukawa, T. Kinoshita, and M. Inukai, J. Am. Chem. Soc. 122 (2000) 10214-10215.

59. M. Inukai, M. Takeuchi, K. Shimizu, and M. Arai, J. Antibiot. 31 (1978) 1203-1205.

60. A. P. Pugsley, Microbiol. Rev. 57 (1993) 50-108

61. D. Cavard, Arch. Microbiol. 171 (1998) 50-58.

62. Y. Paitan, E. Orr, E. Z. Ron, and E. Rosenberg, J. Bacteriol. 181 (1999) 5644-5651.

63. A. Tibor, B. Decelle, and J.-J. Letesson, Infect. Immun. 67 (1999) 4960-4962.

64. N. Banaiee, W. R. Jacobs, and J. D. Ernst, J. Antimicrob. Chemoth. 60 (2007) 414-416.

65. T. Kiho, M. Nakayama, K. Yasuda, S. Miyakoshi, M. Inukai, and H. Kogen, Bioorg. Med. Chem. Lett. 13 (2003) 2315-2318.
66. T. Kiho, M. Nakayama, K. Yasuda, S. Miyakoshi, M. Inukai, and H. Kogen, Bioorg. Med. Chem. 12 (2004) 337-361.

67. B. Cavalleri, H. Pagani, G. Volpe, E. Selva, and F. Parenti, $J$. Antibiot. 37 (1984) 309-317.

68. R. Ciabatti, J. K. Kettenring, G. Winters, G. Tuan, L. Zerilli, and B. Cavalleri, J. Antibiot. 42 (1989) 254-266.

69. J. K. Kettenring, R. Ciabatti, G. Winters, G. Tamborini, and B. Cavalleri, J. Antibiot. 42 (1989) 268-275.

70. M. Kurz and W. Guba, Biochemistry 35 (1996) 12570-12575.

71. D. Shin, Y. Rew, and D. L. Boger, P. Natl. Acad. Sci. USA 101 (2004) 11977-11979.

72. N. J. Skelton, M. M. Harding, R. J. Mortishire-Smith, S. K. Rahman, D. H. Williams, M. J. Rance, and J. C. Ruddock, J. Am. Chem. Soc. 113 (1991) 7522-7530.

73. E. Higashide, K. Hatano, M. Shibata, and K. Nakazawa, $J$. Antibiot. 21 (1968) 126-137.

74. M. Asai, M. Muroi, N. Sugita, H. Kawashima, K. Mizuno, and A. Miyake, J. Antibiot. 21 (1968) 138-146.

75. P. Cudic, D. C. Behenna, J. K. Kranz, R. G. Kruger, A. J. Wand, Y. I. Veklich, J. W. Weisel, and D. G. McCafferty, Chem. Biol. 9 (2002) 897-906.

76. M.-C. Lo, J. S. Helm, G. Sarngadharan, I. Pelczer, and S. Walker, J. Am. Chem. Soc. 123 (2001) 8640-8641.

77. J. B. Hamburger, A. J. Hoertz, A. Lee, R. J. Senturia, D. G. McCafferty, and P. J. Loll, P. Natl. Acd. Sci. 106 (2009) 13759-13764

78. F. Castiglione, A. Marazzi, M. Meli, and G. Colombo, Magn. Reson. Chem. 43 (2005) 603-610.

79. R. Pallanza, M. Berti, R. Scotti, E. Randisi, and V. Arioli, $J$. Antibiot. 37 (1984) 318-324.

80. R. Pallanza, R. Scotti, G. Beretta, B. Cavalleri, and V. Arioli, $J$. Antibiot. 26 (1984) 462-465.

81. H. C. Neu and N. M. Neu, Chemotherapy 32 (1986) 453-457.

82. C. C. Johnson, S. Taylor, P. Pitsakis, P. May, and M. E. Levison, Antimicrob. Agents Chemother. 36 (1992) 2342-2345.

83. L. A. Collins, G. M. Eliopoulos, C. B. Wennersten, M. J. Ferraro, and R. C. Moellering Jr., Antimicrob. Agents Chemother. 37 (1993) 1364-1366.

84. R. N. Jones and A. L. Barry, Diagn. Micr. Infec. Dis. 12 (1989) 279-282.

85. J. Francis, H. Webster, and S. W. B. Newsom, Drug. Exp. Clin. Res. 16 (1990) 457-460.

86. P. A. C. Maple, J. M. T. Hamilton-Miller, and W. Brumfitt, Staphylococcus aureus. J. Antimicrob. Chemoth. 23 (1989) 517-525.

87. L. Gastaldo, R. Ciabatti, F. Assi, E. Restelli, J. K. Kettenring, L. F. Zerilli, G. Romanò, M. Denaro, and B. Cavalleri, J. Ind. Microbiol. Biot. 11 (1992) 13-18.

88. W. Jiang, J. Wanner, R. J. Lee, P.-Y. Bounaud, and D. L. Boger, J. Am. Chem. Soc. 124 (2002) 5288-5290.

89. R. A. Maplestone, J. P. L. Cox, and D. H. Williams, FEBS Lett. 326 (1993) 95-100.

90. W. Jiang, J. Wanner, R. J. Lee, P.-Y. Bounaud, and D. L. Boger, J. Am. Chem. Soc. 125 (2003) 1877-1887.

91. Y. Rew, D. Shin, I. Hwang, and D. L. Boger, Total synthesis and examination of three key analogues of ramoplanin: A lipoglycodepsipeptide with potent antibiotic activity. J. Am. Chem. Soc. 126 (2004) 1041-1043.

92. L. Chen, Y. Yuan, J. S. Helm, Y. Hu, Y. Rew, D. Shin, D. L. Boger, and S. Walker, J. Am. Chem. Soc. 126 (2004) 7462-7463.

93. J. Nam, D. Shin, Y. Rew, and D. L. Boger, J. Am. Chem. Soc. 129 (2007) 8747-8755.

94. X. Yin, Y. Chen, L. Zhang, Y. Wang, and T. M. Zabriskie, J. Nat. Prod. 73 (2010) 583-589.

95. E. A. Somner and P. E. Reynolds, Antimicrob. Agents Chemother. 34 (1990) 413-419.

96. H. Brotz, M. Josten, I. Wiedemann, U. Schneider, F. Gotz, G. 
Bierbaum, and H.-G. Sahl, Mol. Microbiol. 30 (1998) 317.

97. X. Fang, K. Tiyanont, Y. Zhang, J. Wanner, D. Boger, and S. Walker, Mol. Biosyst. 2 (2006) 69-76.

98. M.-C. Lo, H. Men, A. Branstrom, J. Helm, N. Yao, R. Goldman, and S. Walker, J. Am. Chem. Soc. 122 (2000) 3540-3541.

99. J. S. Helm, L. Chen, and S. Walker, J. Am. Chem. Soc. 124 (2002) 13970-13971.

100. D. G. McCafferty, P. Cudic, B. A. Frankel, S. Barkallah, R. G. Kruger, and W. Li, Biopolymers 66 (2002) 261-284.

101. M. Peromet, E. Schoutens, and E. Yourassowsky, Chemotherapy 19 (1973) 53-61.

102. M. Debono, M. Barnhart, C. B. Carrell, J. A. Hoffman, and R. L. Hamill, In: A21978C, a complex of new acidic peptide antibiotics: Factor definition and preliminary chemical characterization, Program and abstracts of 20th intersci. conference on antimicrobial agents and chemotherapy, New Orleans, New Orleans, 1980, p. No. 68.

103. F. T. Counter, P. W. Ensminger, L. C. Howard, In: A21978C, a complex of new acidic peptide antibiotics: Biological activity and toxicity, Program and abstracts of 20th intersci. conference on antimicrobial agents and chemotherapy, New Orleans, New Orleans, 1980, p. No. 69

104. V. Miao, M.-F. Coeffet-LeGal, P. Brian, R. Brost, J. Penn, A. Whiting, S. Martin, R. Ford, I. Parr, M. Bouchard, C. J. Silva, S. K. Wrigley, and R. H. Baltz, Microbiology 151 (2005) 1507-1523.

105. M. Debono, M. Barnhart, C. B. Carrell, J. A. Hoffmann, J. L. Occolowitz, B. J. Abbot, D. S. Fukuda, and R. L. Hamill, $J$. Antibiot. 40 (1987) 761-777.

106. G. M. Eliopoulos, C. Thauvin, B. Gerson, and R. C. Moellering, Jr., Antimicrob. Agents Chemother. 27 (1985) 357-362.

107. A. L. Barry, P. C. Fuchs, and S. D. Brown, Antimicrob. Agents Chemother. 45 (2001) 1919-1922.

108. J. H. Lakey and E. J. A. Lea, BBA - Biomembranes 859 (1986) 219-226.

109. J. A. Silverman, N. G. Perlmutter, and H. M. Shapiro, Antimicrob. Agents Chemother. 47 (2003) 2538-2544.

110. J. H. Lakey, E. J. A. Lea, B. A. M. Rudd, H. M. Wright, and D. A. Hopwood, J. Gen. Microbiol. 129 (1983) 3565-3573.

111. J. H. Lakey, R. Maget-Dana, and M. Ptak, BBA-Biomembranes 1989, 985 (1), 60-66.

112. D. Jung, A. Rozek, M. Okon, and R. E. W. Hancock, Chem. Biol. 11 (2004) 949-957.

113. N. Allen, W. Alborn, J. Hobbs, and H. Percifield, In: LY146032 inhibits the biosynthesis of cell wall peptidoglycan in grampositive bacteria, Program abstract of the 24th international conference on antimicrobial agents and chemotherapy, Washington, DC, 1984; p No. 281.

114. M. Debono, B. J. Abbot, M. R. Molloy, D. S. Fukuda, A. H. Hunt, V. M. Daupert, F. T. Counter, J. L. Ott, C. B. Carrell, L. C. Howard, L. V. D. Boeck, and R. L. Hamill, J. Antibiot. 41 (1988) 1093-1105.

115. F. M. Huber, R. L. Pieper, and A. J. Tietz, J. Biotechnol. 7 (1988) 283-292.

116. J. Grünewald, S. A. Sieber, C. Mahlert, U. Linne, and M. A. Marahiel, J. Am. Chem. Soc. 126 (2004) 17025-17031.

117. J. Grünewald, S. A. Sieber, and M. A. Marahiel, Biochemistry 43 (2004) 2915-2925.

118. F. Kopp, J. Grünewald, C. Mahlert, and M. A. Marahiel, Biochemistry 45 (2006) 10474-10481.

119. R. H. Baltz, P. Brian, V. Miao, and S. K. Wrigley, J. Ind. Microbiol. Biot. 33 (2006) 66-74.

120. K. T. Nguyen, D. Ritz, J.-Q. Gu, D. Alexander, M. Chu, V. Miao, P. Brian, and R. H. Baltz, P. Natl. Acad. Sci. 103 (2006) $17462-17467$.

121. J. Hill, J. Siedlecki, I. Parr, M. Morytko, X. Yu, Y. Zhang, J. Silverman, N. Controneo, V. Laganas, T. Li, J.-J. Lai, D. Keith,
G. Shimer, and J. Finn, Bioorg. Med. Chem. Lett. 13 (2003) 4187-4191.

122. N. E. Allen, J. N. Hobbs, and W. E. Alborn, Jr., Antimicrob. Agents Chemother. 31 (1987) 1093-1099.

123. J. K. Hobbs, K. Miller, A. J. O'Neill, and I. Chopra, J. Antimicrob. Chemoth. 62 (2008) 1003-1008.

124. F. P. Tally, M. Zeckel, M. M. Wasilewski, C. Carini, C. L. Berman, G. L. Drusano, and F. B. Oleson, Jr, Expert Opin. Investig. Drugs 8 (1999) 1223-1238.

125. F. B. Oleson, Jr., C. L. Berman, J. B. Kirkpatrick, K. S. Regan, J. J. Lai, and F. P. Tally, Antimicrob. Agents Chemother. 44 (2000) 2948-2953.

126. R. D. Arbeit, D. Maki, F. P. Tally, E. Campanaro, and B. I. Eisenstein, Clin. Infec. Dis. 38 (2004) 1673-1681.

127. V. G. Fowler, H. W. Boucher, G. R. Corey, E. Abrutyn, A. W. Karchmer, M. E. Rupp, D. P. Levine, H. F. Chambers, F. P. Tally, G. A. Vigliani, C. H. Cabell, A. S. Link, I. DeMeyer, S. G. Filler, M. Zervos, P. Cook, J. Parsonnet, J. M. Bernstein, C. S. Price, G. N. Forrest, G. Fätkenheuer, M. Gareca, S. J. Rehm, H. R. Brodt, A. Tice, and S. E. Cosgrove, New Engl. J. Med. 355 (2006) 653-665.

128. P. E. Pertel, P. Bernardo, C. Fogarty, P. Matthews, R. Northland, M. Benvenuto, G. M. Thorne, S. A. Luperchio, R. D. Arbeit, and J. Alder, Clin. Infect. Dis. 46 (2008) 1142-1151.

129. J. A. Silverman, L. I. Mortin, A. D. G. Vanpraagh, L. Tongcliuan, and J. Alder, J. Inf. Dis. 191 (2005) 2149-2152.

130. K. T. Nguyen, X. He, D. C. Alexander, C. Li, J.-Q. Gu, C. Mascio, A. Van Praagh, L. Mortin, M. Chu, J. A. Silverman, P. Brian, and R. H. Baltz, Antimicrob. Agents Chemother. 54 (2010) 1404-1413.

131. L. D. Boeck, H. R. Papiska, R. W. Wetzel, J. S. Mynderse, D. S Fukuda, F. P. Mertz, and D. M. Berry, J. Antibiot. 43 (1990) 587-593.

132. D. S. Fukuda, R. H. Du Bus, P. J. Baker, D. M. Berry, and J. S. Mynderse, J. Antibiot. 43 (1990) 594-600.

133. D. S. Fukuda, M. Debono, R. M. Molloy, and J. S. Mynderse, $J$. Antibiot. 43 (1990) 601-606.

134. L. D. Boeck and R. W. Wetzel, J. Antibiot. 43 (1990) 607-615.

135. F. T. Counter, N. E. Allen, D. S. Fukuda, J. N. Hobbs, J. Ott, P. W. Ensminger, J. S. Mynderse, D. A. Preston, and C. Y. Wu, J. Antibiot. 43 (1990) 616-622.

136. D. C. Alexander, J. Rock, X. He, P. Brian, V. Miao, and R. H. Baltz, Appl. Environ. Microb. 76 (2010) 6877-6887.

137. D. C. Alexander, J. Rock, J.-Q. Gu, C. Mascio, M. Chu, P. Brian, and R. H. Baltz, J. Antibiot. 64 (2011) 79-87.

138. J.-Q. Gu, D. C. Alexander, J. Rock, P. Brian, M. Chu, and R. H. Baltz, J. Antibiot. 64 (2011) 111-116.

139. C. L. Bender, F. Alarcon-Chaidez, and D. C. Gross, Microbiol. Mol. Biol. Rev. 63 (1999) 266-292.

140. A. Ballio, D. Barra, F. Bossa, J. E. DeVay, I. Grgurina, N. S. Iacobellis, G. Marino, P. Pucci, M. Simmaco, and G. Surico, Physiol. Mol. Plant P. 33 (1988) 493-496.

141. A. Segre, R. C. Bachmann, A. Ballio, F. Bossa, I. Grgurina, N. S. Iacobellis, G. Marino, P. Pucci, M. Simmaco, and J. Y. Takemoto, FEBS Lett. 255 (1989) 27-31.

142. N. Fukuchi, A. Isogai, S. Yamashita, K. Suyama, J. Y. Takemoto, and A. Suzuki, Tetrahedron Lett. 31 (1990) 1589-1592.

143. A. Isogai, N. Fukuchi, S. Yamashita, K. Suyama, and A. Suzuki, Agr. Biol. Chem. 53 (1989) 3117-3119.

144. A. Isogai, N. Fukuchi, S. Yamashita, K. Suyama, and A. Suzuki, Tetrahedron Lett. 31 (1990) 695-698.

145. A. Ballio, F. Bossa, A. Collina, M. Gallo, N. S. Iacobellis, M. Paci, P. Pucci, A. Scaloni, A. Segre, and M. Simmaco, FEBS Lett. 269 (1990) 377-380.

146. N. Fukuchi, A. Isogai, J. Nakayama, and A. Suzuki, Agr. Biol. Chem. 54 (1990) 3377-3379. 
147. A. Ballio, F. Bossa, D. Di Giorgio, P. Ferranti, M. Paci, P. Pucci, A. Scaloni, A. Segre, and G. A. Strobel, FEBS Lett. 355 (1994) 96-100.

148. G. W. Xu and D. C. Gross, J. Bacteriol. 170 (1988) 5680-5688.

149. M. K. Morgan and A. K. Chatterjee, J. Bacteriol. 170 (1988) 5689-5697.

150. M. L. Hutchison and D. C. Gross, Mol. Plant Microbe In. 10 (1997) 347-354

151. M. D. Serra, G. Fagiuoli, P. Nordera, I. Bernhart, C. D. Volpe, D. Di Giorgio, A. Ballio, and G. Menestrina, Mol. Plant Microbe In. 12 (1999) 391-400.

152. A. Ballio, D. Barra, F. Bossa, A. Collina, I. Grgurina, G. Marino, G. Moneti, M. Paci, P. Pucci, A. Segre, and M. Simmaco, FEBS Lett. 291 (1991) 109-112.

153. A. Ballio, F. Bossa, D. Di Giorgio, A. Di Nola, C. Manetti, M. Paci, A. Scaloni, and A. L. Segre, Eur. J. Biochem. 234 (1995) 747-758.

154. A. Isogai, H. Iguchi, J. Nakayama, A. Kusai, J. Y. Takemoto, and A. Suzuki, Biosci. Biotech. Bioch. 59 (1995) 1374-1376.

155. A. Scaloni, L. Camoni, D. di Giorgio, M. Scortichini, R. Cozzolino, and A. Ballio, Physiol. Mol. Plant P. 51 (1997) 259-264.

156. P. Lavermicocca, N. Sante Iacobellis, M. Simmaco, and A. Graniti, Physiol. Mol. Plant P. 50 (1997) 129-140.

157. I. Grgurina, M. Bensaci, G. Pocsfalvi, L. Mannina, O. Cruciani, A. Fiore, V. Fogliano, K. N. Sorensen, and J. Y. Takemoto, Antimicrob. Agents Chemother. 49 (2005) 5037-5045.

158. M. F. Bensaci and J. Y. Takemoto, FEMS Microbiol. Lett. 268 (2007) 106-111

159. K. N. Sorensen, K.-H. Kim, and J. Y. Takemoto, Antimicrob.
Agents Chemother. 40 (1996) 2710-2713.

160. R. Wangspa and J. Y. Takemoto, FEMS Microbiol. Lett. 167 (1998) 215-220

161. S. D. Stock, H. Hama, J. A. Radding, D. A. Young, and J. Y. Takemoto, Antimicrob. Agents Chemother. 44 (2000) 1174-1180

162. C. Julmanop, Y. Takano, J. Y. Takemoto, and T. Miyakawa, J. Gen. Microbiol. 139 (1993) 2323-2327.

163. N. S. Iacobellis, P. Lavermicocca, I. Grgurina, M. Simmaco, and A. Ballio, Physiol. Mol. Plant P. 40 (1992) 107-116.

164. G. Agner, Y. A. Kaulin, P. A. Gurnev, Z. Szabo, L. V. Schagina, J. Y. Takemoto, and K. Blasko, Bioelectroch. 52 (2000) $161-167$.

165. Z. Szabó, P. Gróf, L. V. Schagina, P. V. Gurnev, J. Y. Takemoto, E. Mátyus, and K. Blaskó, BBA - Biomembranes 1567 (2002) $143-149$.

166. K. A. Mott and J. Y. Takemoto, Plant Physiol. 90 (1989) 1435-1439.

167. J. Y. Takemoto, J. L. Giannini, T. Vassey, and D. P. Briskin, Syringomycin effects on plasma membrane $\mathrm{Ca}^{2+}$ transport, in: A. Graniti, R. D. Durbin, and A. Ballio (Eds.), Phytotoxins and plant pathogenesis, Springer-Verlag KG: Berlin, Germany, 1989, pp. $167-175$.

168. H. H. Reidl and J. Y. Takemoto, BBA - Biomembranes 898 (1987) 59-69.

169. H. Batoko, A. de Kerchove d'Exaerde, J.-M. Kinet, J. Bouharmont, R. A. Gage, H. Maraite, and M. Boutry, BBA Biomembranes 1372 (1998) 216-226.

170. F.-S. Che, K. Kasamo, N. Fukuchi, A. Isogai, and A. Suzuki, Physiol. Plantarum 86 (1992) 518-524. 